\title{
AL-KARĪMĪYAH MOSQUE IN ALEPPO, SYRIA: AN ARCHITECTURAL AND ARCHAEOLOGICAL STUDY
}

\author{
Mansour ABD AL-RAZIK \\ Faculty of Archaeology, Cairo University, Egypt. \\ mansour.arch@cu.edu.eg
}

\begin{abstract}
The paper presents a study of the mosque of alKarimiyah, which is considered one of the oldest mosques in Aleppo city. Despite the importance of this mosque, no study has been allocated to it, which gives a special significance of this paper especially that the monuments of the city subject to severe ruin because of the current events in Syria in general. The paper examines the names of the mosque and its historical importance as demonstrated through its various functions. All renewal works at the building are considered and an architectural description is provided, which includes a new dating for some elements, in addition to an analytical study shows the origin of the mosque's elements and compares them to parallel examples. The paper included also a reading for all remaining inscriptions with facsimile figures made by the author and published for the first time. The study also elucidates the endowments that were allocated to the mosque during the Mamluk and the Ottoman periods, demonstrating the significance of its waqf. All plates have been taken by the author in 2010 .
\end{abstract}

الملخص

خُصص ذلك البحث لدراسة جامع الكريمية الذي يُعد - الدئ

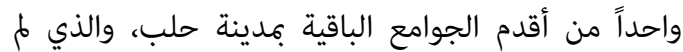

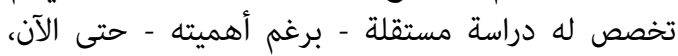

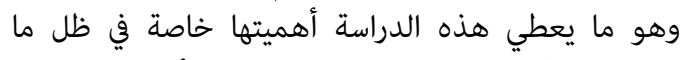

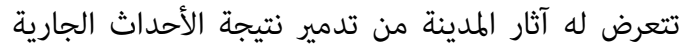

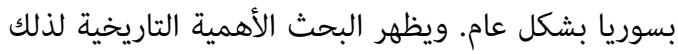

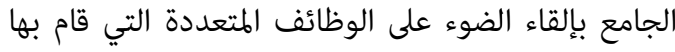

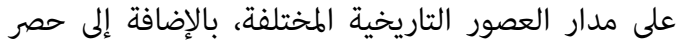

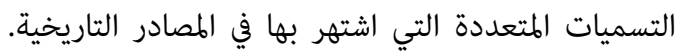

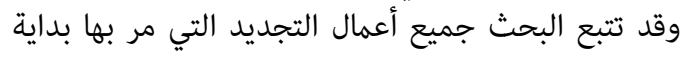

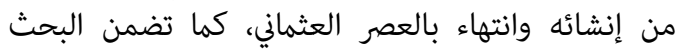

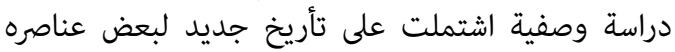

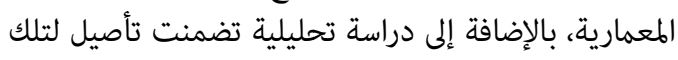

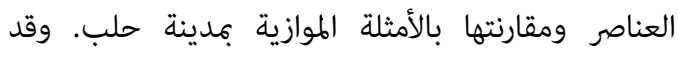
تضمن البحث أيضا قراءة لكافة النقوش الكتابية الباقية مع البادية

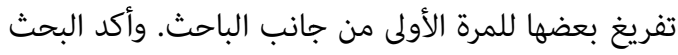

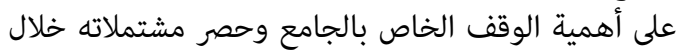
العصرين المملوكي والعثماني مع بيان مصارفه الهمان الشرعية في

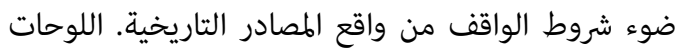

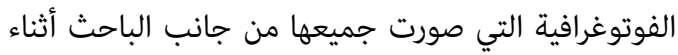
زيارته الميدانية للجامع في 2010م.

\section{KEY WORDS:}

الكلمات الدالة:

Aleppo; al-Karīmīyah mosque; foundation date; Islamic architecture; Islamic inscriptions; minaret; endowments. 


\section{INTRODUCTION}

The city of Aleppo is Syria's second city, located on the river Qūwīq in north-west Syria. It is often regarded as the oldest inhabited city in the world because of its continuous history from at least the twentieth century $\mathrm{BCE}^{1}$. It played a significant historical role during the pre-Islamic periods because of its location on the shortest and most convenient route between the Middle East and the Mediterranean ${ }^{2}$, which made it an important center of civilization. The importance of the city declined during the first three centuries of Islam ${ }^{3}$, but it flourished again from the reign of Hamdanids 332-356 A.H/ 944-967 A.D ${ }^{4}$ to become a base for rule in northern Syria ${ }^{5}$. It remained a place of interest for the rulers of the later Islamic periods, especially under the reign of the Mamluks 658-922 A.H/ 1260-1516 A.D, when it was regarded as a border city ${ }^{6}$.

The city's rulers constructed many monuments across the different Islamic eras to commemorate their memories or as charitable acts. Therefore, the artistic treasures of Aleppo are innumerable. They include the citadel, which is probably the best example extant of medieval military architecture ${ }^{7}$, the fortified city walls and ancient gates, which served as an external shield to protect the city ${ }^{8}$. Many mosques were constructed and spread widely across the city ${ }^{9}$, in addition to madrassas, souks, khans, private homes, and thousands of other architectural elements that represent all periods of Islamic history ${ }^{10}$.

Among the many monumental treasures of the city is the mosque of al-Karimiyah. It is considered one of the oldest mosques in the city, constructed not long after the Islamic conquest, although its exact foundation date is unknown ${ }^{11}$. It is located within the city's borders and its architectural elements still remain in good condition. It is characterized by architectural elements that belong to three successive periods: the Ayyubid, Mamluk, and the Ottoman.

The renewal works undertaken during each of these periods left clear signatures and still remain as a witness to the architectural styles of the time in which they were added. This article demonstrates the archaeological importance of the mosque of alKarimīyah through a description and analytical study of its elements, including their dating. The importance of this study is enhanced by the current unrest in Syrian cities generally, and especially in Aleppo, which threatens various archaeological sites of

\footnotetext{
${ }^{1}$ Petersen, Dictionary of Islamic architecture, p. 10.

2 Chehade, "Aleppo: Its structure and problems", p. 102.

${ }^{3}$ Petersen, Dictionary of Islamic architecture, pp. 10-11.

${ }^{4}$ David \& Hiritani, Halab, p. 59.

${ }^{5}$ Sauvaget, Alep, p. 84.

${ }^{6}$ Sauvaget, Tyrwhitt, “Aleppo", p. 407; Gaube, wirth, Aleppo, p. 51; Burns, Aleppo, p. 168.

${ }^{7}$ Saouaf, Miller, Aleppo, p. 8.

${ }^{8}$ Tabaa, "Circle of power", p. 181.

${ }^{9}$ Warren, "Key monuments of Islamic architecture", p. 231.

10 Roded, "Great Mosques", p. 32.

${ }^{11}$ al-Asadī, Ahìy $\bar{a}$ ' halab, p.107.
} 
different ages. Several sites, including the mosque under study, have been damaged during these events ${ }^{12}$.

\section{AL-KARĪMĪYAH MOSQUE, HISTORICAL BACKGROUND}

Among the monuments of the old city of Aleppo, the mosque of al-Karimiyah is considered one of the oldest archaeological buildings surviving ${ }^{13}$. Unfortunately, we cannot accurately determine the date of the mosque because it does not include any inscriptions giving its first foundation date, and nor is this mentioned in historical sources. The latter do indicate, however, that it was built in an early period after the Islamic conquest ${ }^{14}$, in either the reign of the Caliph 'Umar Ibn al-Khattata or Caliph 'Umar Ibn Abd al-Azīz' ${ }^{15}$. Caliph 'Umar Ibn al-Khattāab ruled between 13-23 AH/ 634644 AD and Caliph 'Umar Ibn Abd al-Azīz reigned between 99-101 AH/ 717-719 AD. Therefore, we can determine the first foundation date of the mosque as between 16 $\mathrm{AH} / 637 \mathrm{AD}$, in which the Arab Muslim armies entered the city of Aleppo, and the year $101 \mathrm{AH} / 719 \mathrm{AD}$ in which the Caliphate of 'Umar Ibn Abd al-Azīz ended noting that this supposition is based on what mentioned in the historical sources about this regard but, as aforementioned, no archaeological evidences. Thus, using the historical sources, we can suppose an approximate foundation date for the mosque during the $1^{\text {st }}$ century AH until the first year of the $2^{\text {nd }}$ century $\mathrm{AH}$.

As for the mosque's names, al-Karimizyah is the current, popular name ${ }^{16}$, although its original name was al-Muhșab, which was mentioned in the historical sources of the Ayyubid period ${ }^{17}$. Unfortunately, the historical sources did not present any explanation for this name, some references referred that it has no origin ${ }^{18}$ and the other mentioned it with no comment ${ }^{19}$. This name may have owned to the supervisor al-mutawali of the mosque in this period that many mosques in the same city were called by the names of their supervisors such as the mosque of al- Amir Ashiqtumur 773 A.H/ 1371 A.D which was famous by al-Sakakini as relate to its supervisor ${ }^{20}$. The name al-Kariminyah is related to al-Shaykh Abd al-Karìm al-Khäfĭ, who renewed the mosque in the Mamluk period ${ }^{21}$. In addition to its original and current names, it

\footnotetext{
12 Shady, Bashar, "Syrian Archaeological Heritage", p. 7.

${ }^{13}$ Talas, Al-Athār al-islāmīyah, p. 93; Nuțfajī, fan al- 'imarah, p. 53.

14 al-Ghuzzī, Nahr al-dhahab, vol. 2, p. 98.

${ }^{15}$ Ibn Shaddād, Al-A 'lāq al-Khațīrah, vol. 1, p. 63.

${ }^{16}$ Many historical sources and references attested that this name correlated with the mosque since the Mamluk period after the renewal works of al-Shaykh Abd al-Karīm al-Khāfì. Ibn al-'Ajamī, Kunūz aldhahab, vol.1, p. 256.; Ibn al-Hanbalī, Durr al- habab, vol. 1, p. 839.; al-Ghuzzī, Nahr al-dhahab, vol. 2, p. 98.; al- Țabbākh, A 'ām al-nublā', vol. 5, p. 287.; Herzfeld, Inscriptions et monuments d'Alep, vol. 2, p. 315.; Gaube, Arabische inschriften aus Syrien, p. 42.; Miencke, Die Mamlukische architektur, p. 372. At the same time, some references referred that the mosque has been famous with this name since the beginning of the $20^{\text {th }}$ century. al-Jāsir, Dür al-mutasawifah, p. 229.

${ }^{17}$ Ibn Shaddād, Al-A 'lāq al-Khațīrah, vol. 1, p. 63.

${ }^{18}$ Herzfeld, Inscriptions et monuments d'Alep, vol. 2, p. 315.

19 al-Jāsir, Dūr al-mutașawifah, p. 229.

20 Ṭalas, Al-'Athār al-islāmīyah, p. 157; al-Jabbūri, al-mushaidāt al-waqfiyah, p. 126.

${ }^{21}$ Miencke, Die Mamlukische architektur, p. 372.
} 
known by the name Masjid al-Qadam, or footprint mosque, as it includes a footprint attributed to the prophet Muhammad ${ }^{22}$.

\section{LOCATION OF THE MOSQUE}

The mosque is situated in a district inside $B \bar{a} b$ Qinnasrin $^{23}$. The quarters which are located inside the city's gates are often named after these gates, such as the quarter of

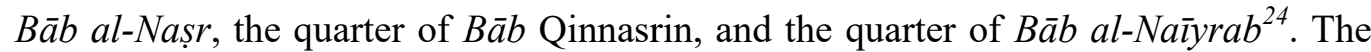
district of $B \bar{a} b$ Qinnasrin is considered one of the oldest districts in Aleppo; this is evidenced by the plans in which the ancient districts of the city were built (Fig. 1).

There are many monumental buildings around the mosque, such as $B \bar{a} b$ Qinnasrin, so named because it leads to the city of Qinnasrin ${ }^{25}$. Other monuments situated in this district include the mosque of al-Tars $\bar{u} s \bar{\imath}^{26}$ and Hammām al-Juharī. ${ }^{27}$

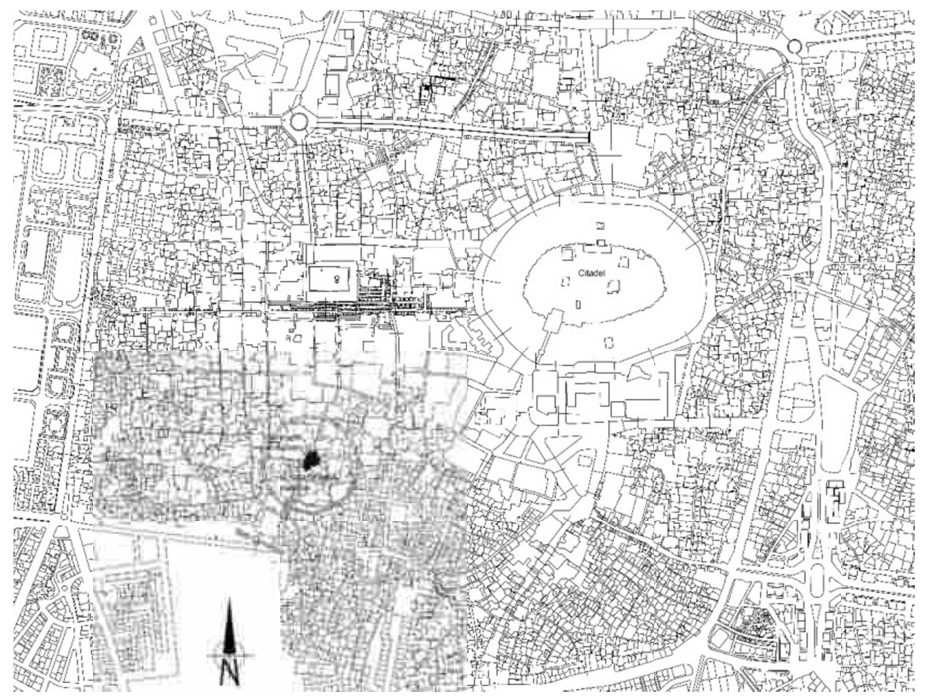

fig.no.1: The map of the old city of Aleppo shows the location of the mosque. After, the center of planning and archaeological studies in Aleppo.

\section{THE RENEWAL WORKS}

The mosque of al-Kariminyah was renewed many times after its first construction. According to historical sources and inscriptions within the mosque itself, the current building attributed to three principal periods: the Ayyubid, the Mamluk, and the Ottoman period.

The mosque was renewed for the first time in the Ayyubid period ${ }^{28}$ during the reign of al-Sultan al-Nāșir Yūsuf II under the supervisor of his slave Abd al-Rahmān Ibn Abd

22 'Uthmān, Al-'Athār wa-l-awābìd al-tārīkhīyah, p. 123.

23 al-Himșī, Halab al-qadīmah, p. 36.

${ }^{24}$ Hivernel, "Bâb al-Nayrab", p. 216.

${ }^{25}$ Bāb Qinnasrin may have been built by Saîf al-Dawlah al-Hamadānī, the ruler of Aleppo between 333-356 AH/ 945-967 AD and was later renewed by al-Malik al-Nāșir Yūsuf II in 654 AH/ 1256 AD. Ibn Shaddād, , Al-A 'lāq al-Khațīrah, vol. 1, p. 19; Qal' ajī, Halab al-qadīmah, p. 105.

${ }^{26}$ the mosque of al-Tarsūsì is attributed to the Zangi period and renewed by Ahmad Ibn al-Tājir in 708 AH/ 1308 AD. al-Ghuzzī, Nahr al-dhahab, vol. 2, p. 101.

${ }^{27}$ Hammām al- Juharī is attributed to al-Amir Aqbugha al-Juharī in 786 AH/ 1383 AD. Abd alRāzik, Al-Hammamāt al- 'āmmah, p. 335. 
al-Rihìm Ibn al- 'Ajamì al-Shāfi $\mathfrak{i}^{29}$ in $654 \mathrm{AH} / 1256 \mathrm{AD}^{30}$. These renewal works are attested in an inscription written by Thuluth, located in the northern entrance ${ }^{31}$. Some researchers consider this date as that of the first construction ${ }^{32}$ but the inscription begins with al-Basmalah, followed by the phrase "this building was renewed...", clearly indicating that these works were renovations after the first construction, as also confirmed by the historical sources.

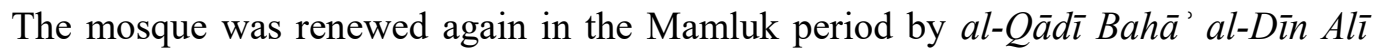
Muhammad Ibn Abi Sawādah ${ }^{33}$, who renewed the minaret in 771 AH/ 1369 AD. These works were proven in an inscription mentioned by Ibn al- 'Ajamī (Kunūz, I, p. 256) and was engraved on the minaret shaft but it has faded and no longer exists.

The main renewal works, however, were undertaken by al-Shaykh Abd al-Karim Ibn Abd Allāh al-Khāfi al- Hanafì in $855 \mathrm{AH} / 1451 \mathrm{AD}^{34}$. He was a student of al-Shaykh Zaīn al-Dìn al-Khäfì, to whom he belonged, and he was one of the dignitaries of Aleppo. He died in $884 \mathrm{AH} / 1479 \mathrm{AD}$ and was buried in a tomb inside the mosque ${ }^{35}$.

The renewal works of al-Shaykh Abd al-Karim are considered the most important in the history of the mosque, and so the building itself was attributed to him. He decided to renew the mosque after adopting it as his place of residence. He demolished the shops adjacent to the mosque on its western side and added their spaces to it, then he expanded its eastern iwan and ordered that Friday prayers should be held at the mosque. These renewal works also included the construction of another entrance beside the old one, new windows in its western side, and toilets for the ablution services $^{36}$. His works were not limited to renewals of the building itself, but also he appointed an Imam for the prayers and Friday sermon and a reader of the Quran ${ }^{37}$. He proclaimed his works in a monumental inscription located above the window of his tomb inside the mosque.

Following this, the mosque was renewed again by al-Amir jāni Bik al-Tājī, the ruler of Aleppo city, in $866 \mathrm{AH} / 1461 \mathrm{AD}$, who renewed many parts of the building and

\footnotetext{
${ }^{28}$ Unfortunately, there is no available information for the several centuries between the foundation of the mosque and its first renewal in the Ayyubid period in $654 \mathrm{AH} / 1256 \mathrm{AD}$. The historical sources provide no notes on the mosque during this period and the building itself does not include any inscriptions before those relating to the Ayyubid renovations in $654 \mathrm{AH} / 1256 \mathrm{AD}$.

${ }^{29} \mathrm{He}$ was captured by the Mongols and murdered in 658 A.H/ 1259 A.D. al-Dhahabī, siyar a ' lām, vol. 1, p. 522.

${ }^{30}$ The same date - $654 \mathrm{AH}$ - was engraved in $B \bar{a} b$ Qinnasrin beside the mosque as a renewal date during the reign of al-Sultan al-Nāșir Yüsuf, indicating that the renovation of the mosque and of $B \bar{a} b$ Qinnasrin were undertaken at the same time.

${ }^{31}$ Herzfeld, Inscriptions et monuments d'Alep, vol. 2, p. 315.

32 'Uthmān, Al-Handasah al-'insh' '̄yah, p. 206.

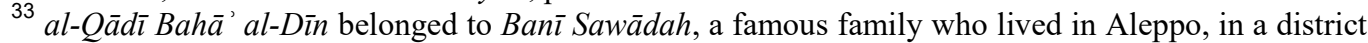

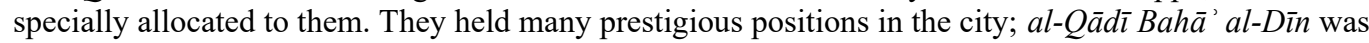
a judge for the city and appointed as a head of Dìwān al-'Inshä'. Ibn al- 'Ajamī, Kunūz al-dhahab, vol. 1, p. 462; Ibn Habib, Tadhkarit, vol. 1, p. 248; Ibn al-Wardī, Tārīkh ibn al-wardī, vol. 2, p. 374; al'Asqalanī, al-Durar, vol. 3, p. 259.

${ }^{34}$ al-Ghuzzī, Nahr al-dhahab, vol. 2, p. 98.

${ }^{35}$ Ibn al-Hanbalī, Durr al- habab, vol. 1, p. 839.

${ }^{36}$ Ibn al- Ajamī, Kunūz al-dhahab, vol. 1, p. 256.

37 al- Țabbākh, A' 'lām al-nublä', vol. 5, p. 287.
} 
added a new minbar ${ }^{38}$. We can thus be certain that the mosque was renewed three times during the Mamluk period. These works are proven by inscriptions, some of which still remain and others of which are now lost but were mentioned in historical sources.

After a period of time, the mosque then fell into ruins and was deserted by worshipers, remaining in that state until it was renewed in $1302 \mathrm{AH} / 1885 \mathrm{AD}$ by Jamil Pasha, the ruler of Aleppo in the reign of al-Sultan Abd al-Hamīd II. These works included many improvements inside the mosque. They are attested in two monumental inscriptions, the first one located above the southern entrance and the second located above the façade of the main iwan. In mentioning the works of Jamil Pasha, we should refer also to Gaube's (1978, p. 42) note that there was once a shop located $150 \mathrm{~m}$ north of the mosque, the façade of which included a monumental inscription with two lines referring to the mosque.

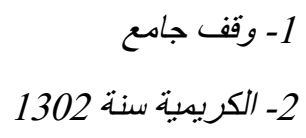

\section{1-This waqf was endowed on the mosque of}

\section{2- al-Karīmīyah in 1302}

The shop no longer exists, but it was recorded, with its inscription, by Gaube (1978, p. $42)^{39}$. The inscription measured $40 \times 20 \mathrm{~cm}$ and indicated that the shop was among the endowments of the mosque and that it was built in $1302 \mathrm{AH} / 1885 \mathrm{AD}$. This date is the same as the works of Jamil Pasha. So, the conclusion can be drawn that the renewal works of Jamil Pasha were not limited to the mosque alone, but also included endowments that were built and allocated to the mosque.

\section{THE FUNCTIONS OF THE MOSQUE}

Although the mosque has four inscriptions, their content is limited to mentions of the names and nicknames of those responsible for renewal works and the dates of these events. None mentions the functions of the mosque, referring to it as a building in general.

The first inscription, for example, belongs to the Ayyubid period. It began with alBasmalah, followed with the phrase "...this blessed building was renewed....." " "........ It is clear that the inscription did not mention a specific function for the building, whether before the renewal works or after their completion $^{40}$.

\footnotetext{
${ }^{38}$ Miencke, Die Mamlukische architektur, p. 372.

${ }^{39}$ This inscription was also photographed and facsimiled by 'Uthmān (2010, p. 149), look at (Fig. 12) at this study.

${ }^{40}$ The same phrase was used in the same city in an inscription commemorating the renewal works of Nür al-Dīn Zanki in al-Hallawīyah madrasa, but the phrase in this case was more specific in that it was complimented by explicit reference to the function of the building: "... this blessed building was

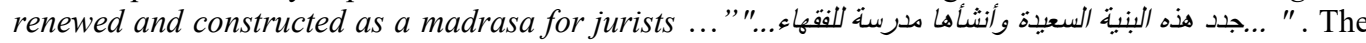
inscription indicated that $N \bar{u} r$ al-Dīn renewed the building in general without any specification
} 
The second of the al-Karimiyah mosque inscriptions is a Mamluk inscription. It is situated in the mausoleum's window and again does not mention the function of the mosque. It begins with a similar phrase: "this blessed place was constructed..." Lُ أنثأ هذا المكان المبارك..." the phrase may refer only to the mausoleum or perhaps to the building in general. The third inscription dated to the Ottoman period and also has no mention of the mosque's functions. The only note regarding the function of the building occurs in the fourth inscription, which belongs also to the Ottoman period. It is located in the façade of al-Qibliyah and in its last verse refers to the building as a mosque . "بدحرم قد جدًّ هذا المسجد

From the preceding discussion, it is clear that the four inscriptions in the building, which belong to three different historical periods, do not provide us with any notes about its function. It is necessary instead to identify the functions of the building from what is mentioned in the historical sources, which indicate that it held a range of roles since its first construction. It was initially limited to holding the five prayers, until it was expanded and renewed in the Mamluk period by al-Shaykh Abd al-Karim ${ }^{41}$. From that time, it became a congregational mosque ${ }^{42}$ and the Friday prayer was held inside $i t^{43}$. In discussing its function, Herzfeld $(1955$, p. 372) referred to it as almadrasa al-Karimiyah, but the historical sources do not mention any notes about this function. Some historical sources do refer to it as a Zāwìyah, such as Ibn al-Hanbalī (Durr, I, p. 839), who said in the biography of al-Shayh Abd al-Karīm "Abd al-Karìm Ibn Abd Allāh al-Khāfì al-Hanafì the owner of the famous Zāwīyah inside bāb Qinsarin..."

Herzfeld also added a new function. He assumed that the mosque played the role of al-Khanqāh, and was known as al-khanqāh al-Shamsīyah ${ }^{44}$. Although the historical sources do not comment that the mosque played this role ${ }^{45}$, this assumption may be logical, especially after it was renewed under the patronage of al-Shaykh Abd alKarim al-Khäfì, who was famous for his Sufis activity. This is further supported by

regarding its function, but showed also that the building after these renewal works became a madrasa for jurists, noting that the building was used as a mosque before the works of Nür al-Dīn. Ibn Shaddād, Al-A 'āq al-khațīrah, vol. 1, p. 111.; al-Jirmānī, Tuhaf al- 'anba',p. 200.; Herzfeld, Inscriptions et monuments d'Alep, vol. 2, p. 315.; al-Jāsir, Madāris halab, p. 109.

${ }^{41}$ Ibn al-Ajamī, Kunūz al-dhahab, vol. 1, p. 256.

42 The mosque was mentioned among the lists of the congregational mosques that were mentioned in the contemporary sources of the Mamluk period. Ibn al-Ajamī, Kunūz al-dhahab, vol. 1, p. 256; Ibn alShuhnah, Al-Durr al-muntakhab, p.72; Gaube, Wirth, Aleppo, p. 235.

${ }^{43}$ Meincke, Die Mamlukische architektur, p. 372.

${ }^{44}$ Herzfeld, Inscriptions et monuments d'Alep, vol. 2, p. 315.

${ }^{45}$ Ibn Hajar al- 'Asqalanī referred in his book (inba', vol. 3, pp. 138-141) during his translation of alShaykh Muhamad Ibn Bahadir Ibn Abdullah al-Zarkashī that he assumed the position of Shaykh in alKhanqah al-Karīmīyah. Al-'Asqalanī did not determined if he mean the mosque of al-Karīmīyah in Aleppo or al-Khanqah al-Karīmīyah in Cairo as al-Shaykh al-Zarkahī frequented to Aleppo and Cairo during his life. The same historian translated to al-Shaykh al-Zarkahī in his book (al-Durar, vol. 3, pp. 397-398) and stated that al-Zarkahī appointed as Shaykh in khanqat Karim al-din. It is proved that al'Asqalanī intended al-Khanqah al-Karīmīyah in Cairo which was situated in al-Qarafah al-Sughra and constructed by al-Amir Karim al-din Ibn al-Sadid in 722 A.H/ 1322 A.D. al- 'Asqalanī, inba', vol. 1, p. 447; al-'Asqalanī, al-Durar, vol. 3, p. 398; Said, “Kahnqahat misr”, p. 1455.

\footnotetext{
- 207 - Al-Karīmīyah Mosque in Aleppo, Syria: An Architectural \& Archaeological Study
} 
the fact that this man was one of the students of al-Shaykh Zain al-Dinn al-Khäfi, who was a famous Sufi man. al-Shaykh Abd al-Karim was a close student of his and took his name -al-Khäfi- as a nickname ${ }^{46}$. Therefore, it is likely that al-Shaykh Abd alKarim made the mosque a refuge for the Sufis after he renewed it.

In addition to these functions, the mosque includes a mausoleum added by al-Shaykh Abd al-Karim as his own tomb ${ }^{47}$. It was also used as a shrine because it includes a footprint on a marble slab incorrectly attributed to the prophet Muhammad. From the preceding, it is clear that the mosque of al-Karimiyah played various functions and had great importance among the mosques of Aleppo city.

\section{ARCHITECTURAL DESCRIPTION AND ANALYTICAL STUDY}

The mosque occupies an irregular area with a total $1350 \mathrm{sq} \mathrm{m}$. It has only one free façade, which overlooks the adjacent street. The façade has two entrances and only one minaret, surmounting the southern entrance. Inside the mosque, there are many architectural units, such as the main iwan, a side portico, a mausoleum, and other extensions. All the architectural units inside the mosque share one open courtyard (Fig. 2).

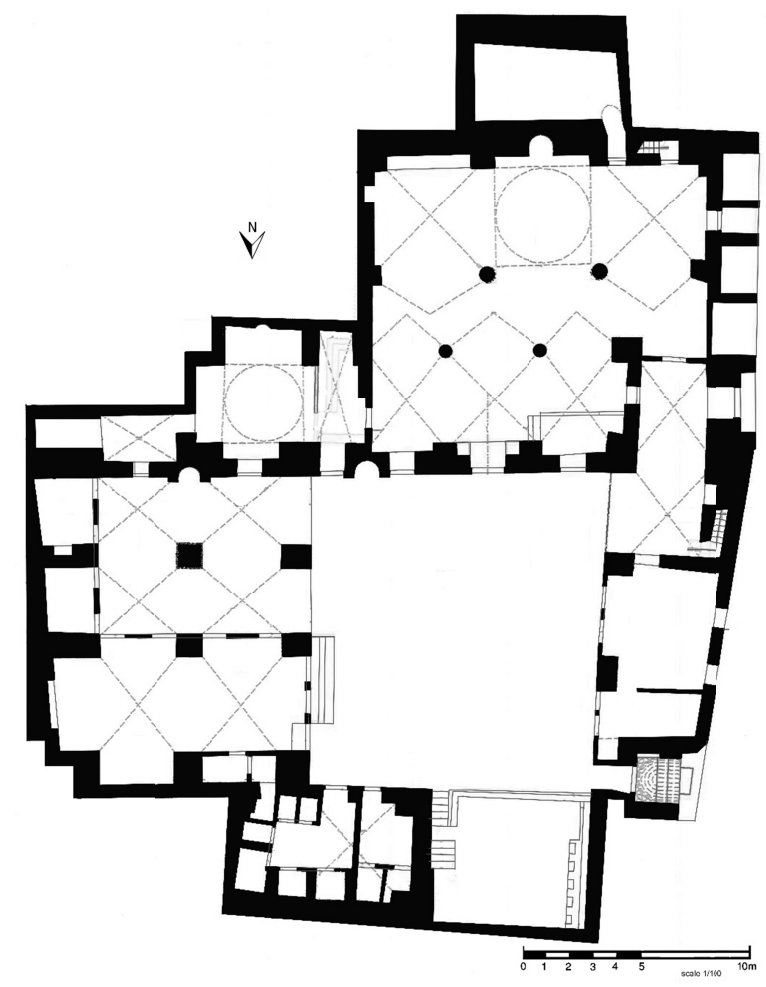

fig.no.2: The plan of the mosque. After, The center of planning and archaeological studies in Aleppo.

\section{The façade:}

The mosque has only one façade overlooks the $B \bar{a} b$ Qinnasrin street. Its length is $30.15 \mathrm{~m}$, and it is $5.60 \mathrm{~m}$ high from the level of the outside street, which is now at a level $80 \mathrm{~cm}$ above the base of the façade. At the top of the façade there is a renewed

\footnotetext{
46 al-Sakhāwī, Al-Daw' allāmi', vol. 9, p. 260.

${ }^{47}$ Meincke, Die Mamlukische architektur, p. 372.
} 
surmounting wall measuring $1.80 \mathrm{~m}$ high, which means that the overall height of the façade today is $8.20 \mathrm{~m}$ (Fig. 3). The façade is characterized by its simplicity and is devoid of decorations except a projecting stone cornice at its top (Pl. 1).

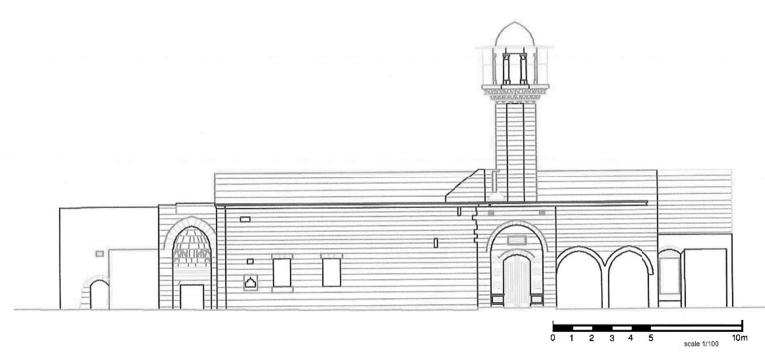

fig.no.3: The façade of the mosque, the two entrances, and the minaret. After, the center of planning and archaeological studies in Aleppo.

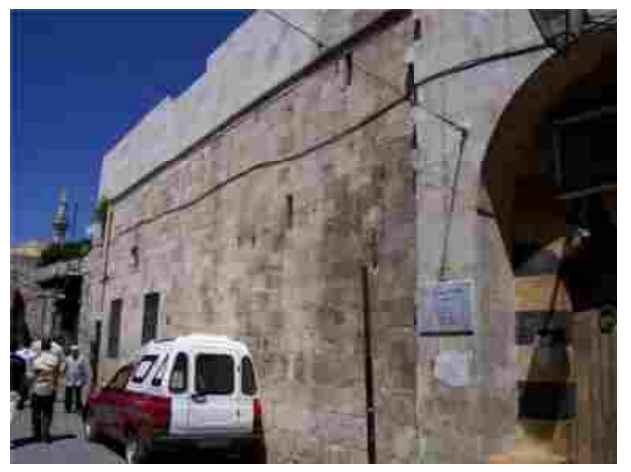

Pl.no.1 The façade of the mosque. By the author in July 2010.

The southern section of the façade is occupied by three shops. These were probably among the endowments allocated to the mosque during the works of al-Shaykh Abd al-Karim in $855 \mathrm{AH} / 1451 \mathrm{AD}$, since the historical sources mention that his expansions were in the western side ${ }^{48}$, where the three shops are located. The first and the second shop overlook the outside street via a pointed arch; they are adjacent to the southern entrance from the south side. The third shop overlooks the outside street through a flat arch and is separated by a small window (Fig. 3). This window connects the main iwan and the external façade through a short corridor roofed by a pointed vault $2.30 \mathrm{~m}$ long. The window rises over the street level by $70 \mathrm{~cm}$ and reaches 2.30 $\mathrm{m}$ high. It is topped by a curved arch, and covered by a veil of iron grill.

In the north side of the façade, there are other two windows. They were added during the works of al-Shaykh Abd al-Karim ${ }^{49}$. They have the same height of $1.40 \mathrm{~m}$, and same width of $90 \mathrm{~cm}$, and they are covered by iron grilles. Beside the two windows on the south side, there is a Qastal for drinking water comprised of a deep recess topped by a pointed arch (Pl. 1). It represents the common style found in many monumental buildings of the city, most of which have a small recess with a pottery pipe which provides them with water. The Qastal appeared in many building's facades, such as the mosque of al-Shu' iybiyah, which is considered the first mosque constructed in the city (Raby 2004, 289). The Qastal also occurs in many facades during the Mamluk period, such as the façade of Mihmindār mosque $8^{\text {th }} \mathrm{AH} / 14^{\text {th }} \mathrm{AD}$ which includes a Qastal in its western side. It appears as well in the facades of many Ottoman buildings, such as that of Bahrām pasha mosque in al- Jallūwm district $991 \mathrm{AH} / 1583$ $\mathrm{AD}^{50}$.

\footnotetext{
${ }^{48}$ Ibn al-Ajamī, Kunīz al-dhahab, vol. 1, p. 256.

${ }^{49}$ Ibn al-Ajamī, Kunīz al-dhahab, vol. 1, p. 256.

50 Abd al-Rāzik, "Mosque of Bahram Basha", p. 4.
} 
The current mosque includes only one façade, we cannot state if it included sidefacades as there is no available information about its first construction. By any way, single façades, as found at the al-Karimiyah mosque, are a common feature in many mosques of the city in the Mamluk period as well as earlier and later periods. Among the mosques that include only one façade are: the mosque of $A b \bar{u}$ Yahīa al-Kawākibi in al-Jallūwm district dating to $628 \mathrm{AH} / 1220 \mathrm{AD}$; al-Zaki mosque in Bāb al-Nașr street dating to $700 \mathrm{AH} / 1300 \mathrm{AD}$; al-S Sirawi mosque in al-Bayādah district dating to $780 \mathrm{AH} / 1378 \mathrm{AD}$; and al-Sakākīnì in al-A jām district dating to $773 \mathrm{AH} / 1371 \mathrm{AD}$. The façade of the al-Karimiyah mosque is very simple, as in the majority of facades of the city's mosques, except for the inscriptions and the color rotation around the entrance. The same simplicity is seen elsewhere, such as the façade of al-Atrüsh mosque behind the justice palace, built in $812 \mathrm{AH} / 1409 \mathrm{AD}$, and al-Daraj mosque in khān al-Sabīl district dating to $9^{\text {th }} \mathrm{AH} / 15^{\text {th }} \mathrm{AD}^{51}$.

\section{The entrances:}

The mosque has two entrances located in its façade. The first, located in the north side, is the oldest one; it was added during the renewal works of the Ayyubid period in $654 \mathrm{AH} / 1256 \mathrm{AD}$. It comprises a huge recess measuring $5.10 \mathrm{~m}$ high from its base, and $2 \mathrm{~m}$ in width. It is surmounted by a semi-dome with a pointed sector based on three squinches in each of the two inner corners. Inside the recess, there is the door that leads inside. It measures $2.10 \mathrm{~m}$ high from its base, and is $1.15 \mathrm{~m}$ wide. A flat marble lintel surmounts it, and it is closed by two wooden shutters (Pl. 2). In the southern side of the recess, there is a small door khwkhah surmounted by a curved arch and led to the adjacent room but it is closed now and no longer used. This small door added in a later period and did not back to the original entrance, it made from the northern entrance a rare style that no previous example in the city includes a small door in both sides of its recess. ${ }^{52}$

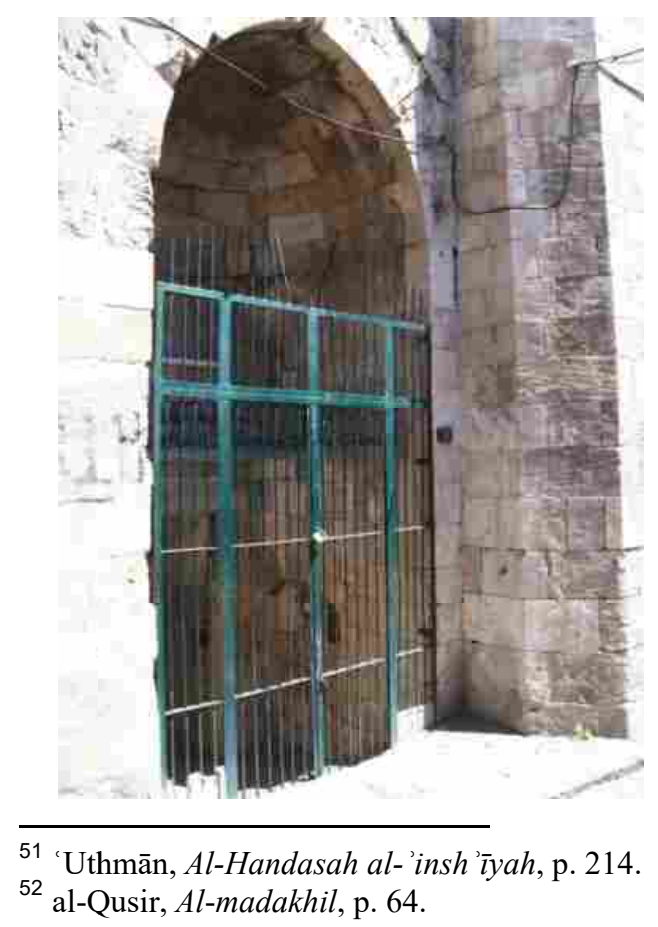

P1.no.2 The northern entrance and the Ayyubid inscription. By the author in July 2010 .. 
The entrance includes an inscription ${ }^{53}$ composed of two lines, wrapping around the three sides of the recess. It rises over the entrance level by $2.85 \mathrm{~m}$; its length is $1.56 \mathrm{~m}$ at the right side, $2.06 \mathrm{~m}$ in the middle, and $1.56 \mathrm{~m}$ at the left side; and it has a width of $28 \mathrm{~cm}$ along all three $\operatorname{sides}^{54}$ (Fig. 4).

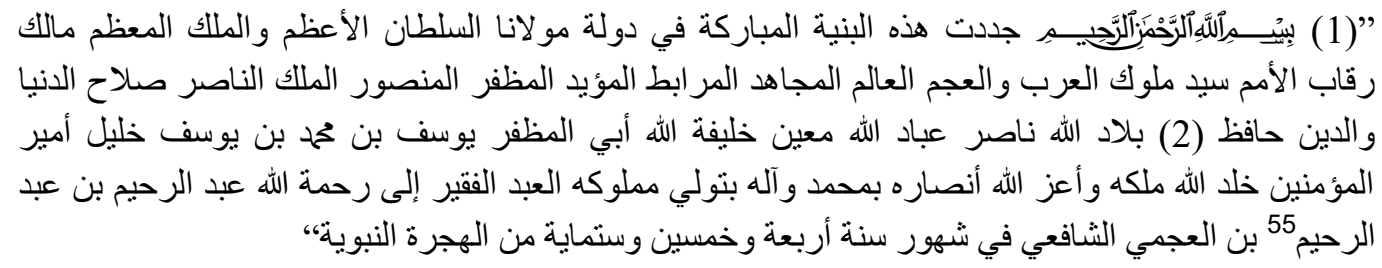

"(1) Al-Basmalah, this blessed building was renewed in the reign of al-sultān alA 'zam wa-l-Malik al-Mu 'azzam Mālik Riqāb al-'Umam Saìd Mulūwk al-'Arab wa-l'Ajam al-'Ālim al-Mujāhid al-Murābit al-Mu'ā̄yad al-Muzaffar al-Manșūr al-Malik al-Nāșir Șalāh al-Dunyā wa-l-Dīn protector (2) the countries of Allāh helper the slaves of Allāh helper of the caliphate of Allāh Abī al-Muzaffar Yūsuf Ibn Muhammad Ibn Yüsuf Khalīl Amīr al-Mu'minīn Allāh immortalized his kingdom and blessed his supporters by the prophet Muhammad and his family under the supervisor of his poor slave Abd al-Rahìm Ibn Abd al-Rahìm Ibn al-Ajamì al-Shäfi 'ì in 654 from the migration of the Prophet"

Fig. 4: The Ayyubid inscription in the northern entrance. Facsimiled by the author.

The inscription belongs to the Ayyubid period and is written with Thuluth script, although the majority of the Ayyubid inscriptions were written with Naskhi script. Thuluth script was occasionally used jn this period, beginning to appear in the $4^{\text {th }} \mathrm{AH}$ century/ $10^{\text {th }} \mathrm{AD}^{56}$. The Naskhi script was the official script for registration in monumental buildings in this period, however, with the first example recorded in the city's monuments dated to $543 \mathrm{AH} / 1148 \mathrm{AD}$, located above the entrance of alHallawiyah madrasa. All previous inscriptions were written with Kufic script ${ }^{57}$.

\footnotetext{
${ }^{53}$ This inscription was read in the historical sources such as: Ibn al-Agami (kunūz, vol. 1, p. 256); alGhuzzi (nahr, vol. 2, p. 99) and previously published by Herzfeld (1956, p. 315) but it is facsimiled for the first time at this study (Fig. 4).

${ }^{54}$ Herzfeld, Inscriptions et monuments d'Alep, vol. 2, p. 315.

55 This phrase was read by Herzfeld as “........” but it is more correct to read as found in the inscription as “........”. Herzfeld, Inscriptions et monuments d'Alep, vol. 2, p. 315.

${ }^{56}$ al- Jabbūrī, Al-Khat wa-l-kìtābah, p. 130.

57 'Uthmān, Al-Athār wa-l-awābìd al-tārīkhīyah, p. 203.
}

- 211 - Al-Karīmīyah Mosque in Aleppo, Syria: An Architectural \& Archaeological Study 
The second entrance is located in the south side of the façade; it was added during the renewal works of al-Shaykh Abd al-Karim in 855 AH/ 1451 AD. It comprises a huge recess surmounted by a pointed arch, which reaches $4.35 \mathrm{~m}$ from the street level and is $2.70 \mathrm{~m}$ wide. In both the right and left sides of the recess, there is a terrace $74 \mathrm{~cm}$ high and a $63 \mathrm{~cm}$ wide. Inside the recess is the entrance that leads inside the mosque. It is surmounted by a curved arch composed of engaged voussoirs, measuring $2.76 \mathrm{~m}$ high and $1.40 \mathrm{~m}$ wide. It is closed by two wooden shutters. The façade of this entrance is characterized by its simplicity. It has no decoration except the color rotation of the stones between black and yellow, according to the al-Ablaq style (Pl. $3)$.

The entrance has an inscription located above its curved arch (Fig. 5), the text added during the renewal works of Jamīl Pasha in 1302 AH/ 1885 AD. It comprises three lines written in Turkish language, referring to the renewal works in the reign of alSultan Abd al- Hamìd II under the supervisor of Jamill Pasha, the ruler of Aleppo city. The date of these renewal works has been engraved under the three lines by numbers $1302 \mathrm{AH}$.

$$
\begin{aligned}
& \text { 1- خليفة إسلام بناه وشهنشاه شوكت أكتناه شوكتاو } \\
& \text { 2- الغازي عبد الحميد خان ثاني أفندمز حضرتلرينك عهد همايونلرنده } \\
& \text { 3- حلب و لايتي و اليسي جميل بانشانك دلالت .... مكملا تعمير أولنمشدر } \\
& \text { سنة } 1302
\end{aligned}
$$

1- The caliph of Islam, the lord of the kings, and the possessor of greatness

2- In the blessed reign of the conqueror abd al-hamìd II

3- the ruler of Aleppo Jamill pasha renovated .... at the best way

In 1302

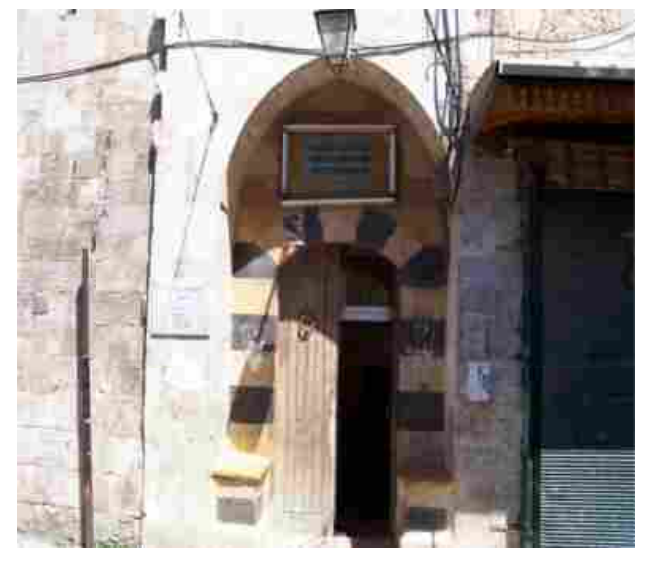

Pl.no.3: The southern entrance and the Turkish inscription of the renewal works of Jamīl pasha. By the author in July 2010..

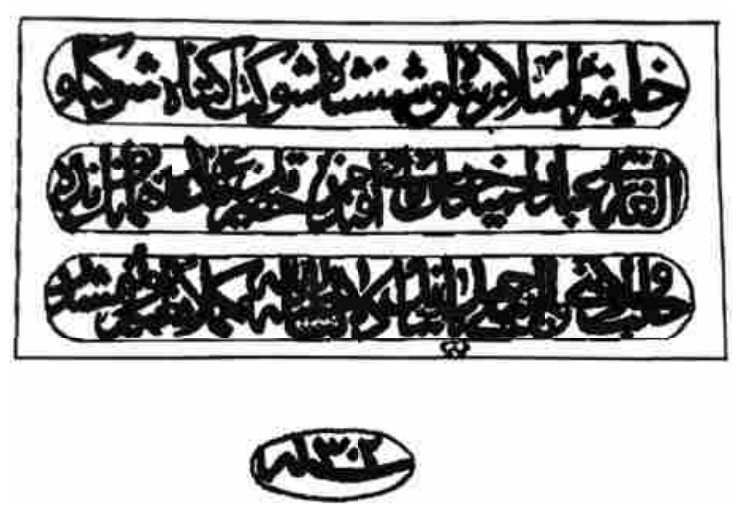

fig.no.5: The Turkish inscription which located above the southern entrance. After, 'Uthmān, Dirasat naq' ish, p. 148. 
The mosque therefore includes two entrances in its façade, as found in many other mosques of different periods in the city of Aleppo. The two entrances are located in the same side in al-Karimiyah mosque, but this was rare among the city's mosques. For example, the great Omayyad mosque has two entrances, the first located in the western side and the second is in the northern side. In al-Tunbügha mosque, dating to $718 \mathrm{AH} / 1318 \mathrm{AD}$, the first is located in the eastern side and the second is in the western side. In al-Atrūsh mosque of $812 \mathrm{AH} / 1409 \mathrm{AD}$, the first is located in the western side and the second is in the northern side. In al-Tawāsh $\bar{\imath}$ mosque built in 774 $\mathrm{AH} / 1372 \mathrm{AD}$, the first entrance is in the eastern side and the second is located in the western $\operatorname{side}^{58}$.

The two entrances of the mosque have two different styles. The older one is comprised of a recess surmounted by a half-dome based on stalactites (P1. 2). The same shape appears in the entrance of the Mihmindār mosque, which features a huge recess surmounted by a half-dome with a pointed sector based on stone stalactites ${ }^{59}$. The second entrance comprises a recess surmounted by a pointed arch (Pl. 3). This shape appears in many other examples, such as the entrance of Ogelbek mosque in alBāb al-Ahmar district, built in $885 \mathrm{AH} / 1480 \mathrm{AD}^{60}$.

\section{The minaret}

The mosque has only one minaret, located above the southern entrance. It was said to

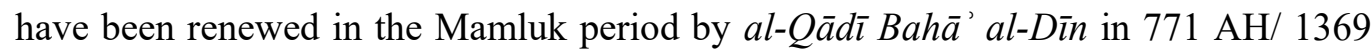
$\mathrm{AD}$ according to an inscription mentioned by Ibn al-Ajamī (Kunz̄z, I, p. 256) who read it as follows:
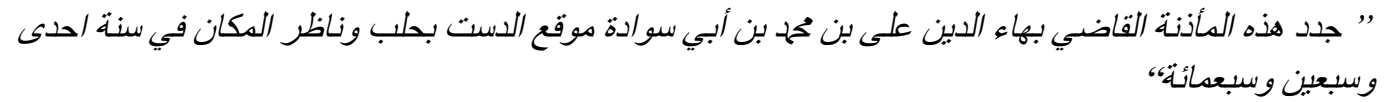

"This minaret was renewed by al-Qādī Bahā" al-Dīn Alì Muhammad Ibn Abī Sawādah Müwaqqi 'al-Dist ${ }^{61}$ in Aleppo and the supervisor of the place in 771 AH"

It is illogical, however, that the current minaret is of this date, because it is constructed above the southern entrance, which was only added to the mosque during the renewal works of al-Shaykh Abd al-Karim in $855 \mathrm{AH} / 1451 \mathrm{AD}$. The entrance forms the base of the minaret itself (Fig. 3). Therefore, I suggest that the minaret was completely renewed again during the works of al-Shaykh Abd al-Karim in $855 \mathrm{AH} /$ $1451 \mathrm{AD}$ or those of al-Amir Jānī Bik al-Tājī in $866 \mathrm{AH} / 1462 \mathrm{AD}$. This is supported by the inscription mentioned by Ibn al-Ajamī (Kunūz, I, p.256), which is eroded and no longer exists, but refers to the minaret being renewed in a later period. The current minaret was also constructed according to the Mamluk style, which proves that it was

58 'Uthmān, Al-Handasah al-'insh' '̌yah, p. 211.

59 Abd al-Rāzik, “Architectural archaeological study”, p. 147.

60 'Uthmān, Al-Handasah al-'insh '̄yah, p. 220.

${ }^{61}$ Mūwaqqi al-Dist means: the Sultan's writer or Kätib al-Dist al-sultānī, he was a first-class employee in Diwān al-insha'. Also, he was sitting with Kätib al-sir during the Sultan's meetings, he read the orders, decisions to the Sultan and signed it. Ibn al-Hanbalī, Durr, vol. 1, p. 616. 
renewed during the aforementioned works, as they were the only renovations in the Mamluk period after the date $771 \mathrm{AH}$.

In stylistic terms, the current minaret is very simple and devoid of decoration and inscriptions. It resembles other minarets constructed in the city in the Mamluk period. It begins over the roof, at $9.45 \mathrm{~m}$ high. It has one octagonal shaft of $5.20 \mathrm{~m}$ height, and ends at its top with a projecting balcony of octagonal shape, based on stone stalactites. At the top, there is a cupola with a pointed sector ( $\mathrm{Pl} .4)$.

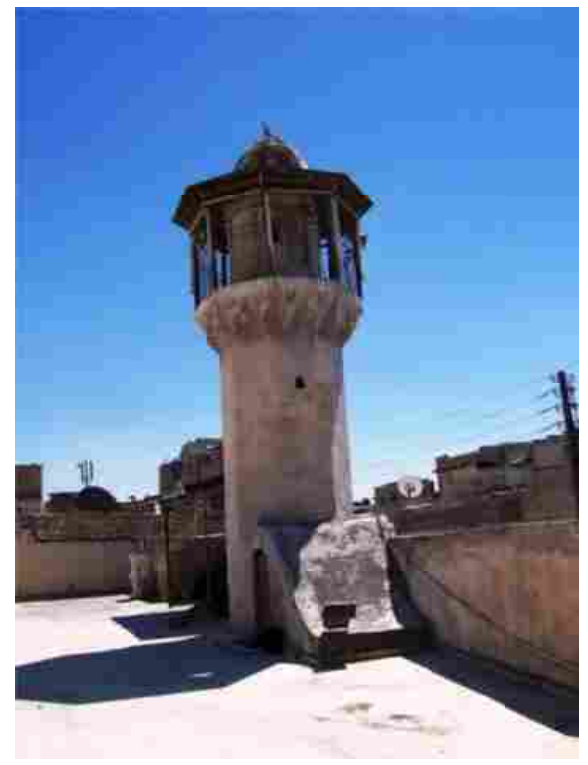

Pl.no.4: The minaret of the mosque. By the author in July 2010.

It was a common rule among the religious buildings in the city of Aleppo that no mosque should have more than one minaret. The minaret of the al-Karimiyah mosque belongs to the Mamluk style, which often utilized the octagonal shape. Square minarets were common in previous times, during the Seljuk, Zanki, and Ayyubid periods, such as the minaret of the great Omayyad mosque of the Seljuk period built in $483 \mathrm{AH} / 1090 \mathrm{AD}$, which is considered the oldest surviving minaret in the city of Aleppo $^{62}$. It is thought that the square minaret first appeared in Syria and after that spread across the western and eastern Islamic world ${ }^{63}$.

The style of the minaret of al-Karimizah appeared in many other examples during the Mamluk period. These include the minaret of al-Asfar mosque in al-Jallüwm district, which was renewed during the Mamluk period; the minaret of al-Haīyyāt mosque in al-Farafrah district of $727 \mathrm{AH} / 1326 \mathrm{AD}$; the minaret of al-Haddādin mosque in Banqūsa district dating to $743 \mathrm{AH} / 1342 \mathrm{AD}$; and the minaret of al- 'Umarì mosque in Bahsitta district of $8^{\text {th }} \mathrm{AH} / 14^{\text {th }} \mathrm{AD}^{64}$. All these examples including the minaret of alKarimizyah have only one balcony that no minaret in Aleppo in general features more than one balcony except the minaret of al-Atrūsh which include two octagonal shafts

\footnotetext{
${ }^{62}$ Fares, The Great Umayyad mosque, p. 32.

${ }^{63}$ Creswell, "The Evolution of the minaret", p. 134.

64 Abd al-Rāzik, “Al-Ṭuruz al-mi 'mārìyah”, pp. 316-318.
} 
each one surmounted by balcony ${ }^{65}$. Also, there is no one example of the minaret of Aleppo covered entirely with tiles except the minaret of al-Khusrawiyah which includes a single row of tiles rings its lower part ${ }^{66}$.

\section{Inside the mosque}

There are two entrances leading to the inside. The first one is located in the northern side of the façade and leads directly to the open courtyard through a short corridor roofed with a pointed vault, but it is now closed and no longer used. The second one is located in the southern side of the façade. It leads to a transversal corridor $8.39 \mathrm{~m}$ long and $2.88 \mathrm{~m}$ wide, and roofed with two cross vaults. Inside the corridor, there is a window located in the right side and open to the main iwan. There is also a small door facing the outer entrance which leads directly to the main iwan, while the left side of the corridor leads to the open courtyard. On the northwestern side, there is the entrance that leads to the roof and the minaret through a stone staircase. It is $1.90 \mathrm{~m}$ high and $70 \mathrm{~cm}$ wide, and a curved arch surmounts it (Fig. 2).

\subsection{The open courtyard}

All the architectural units inside the mosque share one courtyard, which has a semisquare shape measuring $13.55 \mathrm{~m}$ long and 12.47 wide (Fig. 2). The old courtyard was open and not roofed but is now covered by a modern roof. Its floor is paved with slab stones and has no decoration or fountain as usual. There are four facades overlooking it: the first in the south side is the façade of the main iwan, the second in the east side of the façade of the eastern iwan, and the third and the fourth in the northern and western sides of the facades of the mosque's extensions.

\subsection{The main iwan, al-Qiblīyah:}

The main iwan is situated in the south side of the courtyard and overlooks its interior with a stone façade 6.70 high and finished at its top by a projecting stone cornice. In the middle of the façade lies the entrance of the main iwan or al-Qibliyah, with a height of $2.65 \mathrm{~m}$ and width of $1.40 \mathrm{~m}$. The entrance is surmounted by a curved arch, and two wooden shutters close it. The façade has three windows, two of which open onto the main iwan, while the third overlooks the ablution room that separates the main iwan and the mausoleum. The three windows have the same dimensions, with a height of $2.10 \mathrm{~m}$ and width of $1.10 \mathrm{~m}$, and each is surmounted by a curved arch and covered by an iron grille. The façade also includes a mihrab overlooking the inside of the courtyard, which seems to have been added in a later period as resembles a new extension and its color differs from the façade's wall. It comprises a niche surmounted by a pointed arch measuring $2.60 \mathrm{~m}$ high and 1.12 wide (Fig. 6; Pl. 5).

65 Abd al-Rāzik, “Al-Ṭuruz al-mi mārīyah”, p.330.

66 Wantenpaugh, The image of an Ottoman city, p. 226.

- 215 - Al-Karīmīyah Mosque in Aleppo, Syria: An Architectural \& Archaeological Study 


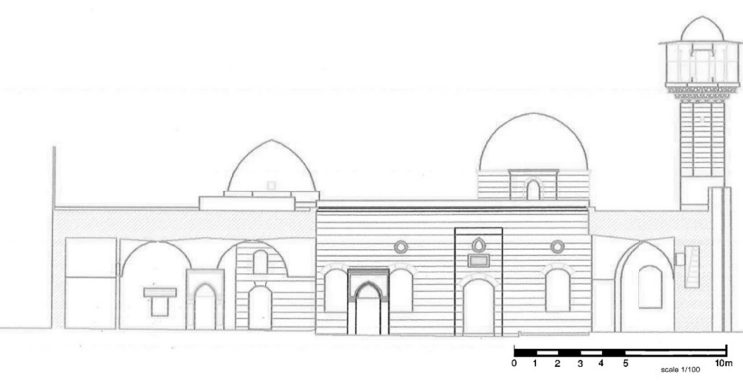

fig.no.6: Sector shows the façade of al-Qiblīyah, inside the eastern portico, and the two domes of the main iwan and the mausoleum. After, the center of planning and archaeological studies in Aleppo.

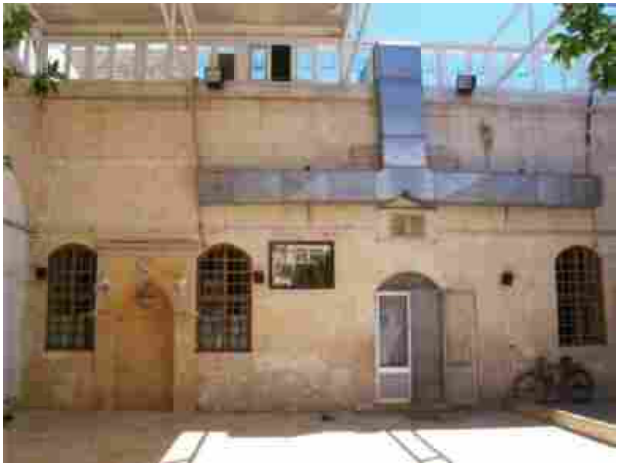

pl.no.5 The façade of al- Qiblīyah and the Ottoman inscription of the renewal works of Jamīl pasha. By the author in July 2010.

The façade of the main iwan includes also a monumental inscription ${ }^{67}$ located above the entrance. It refers to the renewal works that occurred at the mosque in the Ottoman period in $1302 \mathrm{AH} / 1885 \mathrm{AD}^{68}$, comprising five poetry verses written in Thuluth script carved prominently on stone (Fig. 7).

$$
\begin{aligned}
& \text { وغدت نضارة حسنه تتوقد } \\
& \text { عبد الحمبد له الثنا و السؤدد } \\
& \text { فينا جميل صنائع لا تنفل } \\
& \text { نولي المكارم والمفاخر أحمد } \\
& \text { بدحرم قد جدَّ هذا المسجد }
\end{aligned}
$$

$$
\begin{aligned}
& \text { بعد الاثور لله أتبح تجددا }
\end{aligned}
$$

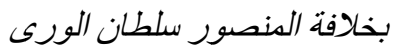

$$
\begin{aligned}
& \text { وبسعي والينا جمبل من له } \\
& \text { ونضارة الندب الههام العادلي ولي } \\
& \text { مذ صحح بعد الوهن أرخ مدحه }
\end{aligned}
$$

1302

"After the demolition, it was renewed and became in a good condition in the reign of al-sultan Abd al- Hamid II who deserves the praise and under the supervisor of his deputy Jamill pasha who is credited with many good deeds, the renovation of this mosque was in Muharram 1302 AH"

The date of this renewal works was recorded by numbers at the bottom, as well it was recorded by letters in the last verse "مدحه بدحرمقد جدً هذا المسجد" according to Hisāb aljumal (table 1).

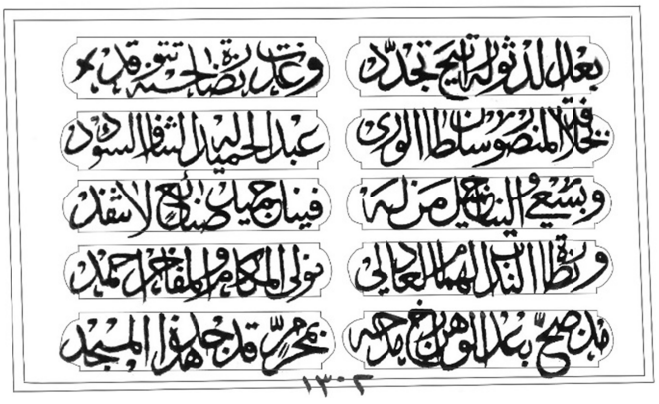

Fig.no.7: The Ottoman inscription of the renewal works of Jamil pasha.

Facsimiled by the author.

\footnotetext{
67 This inscription was read by al-Ghuzzi (nahr, vol. 2, p.99) and previously published by Gaube (1978, p. 42).

${ }^{68}$ Gaube, Arabische inschriften aus Syrien, p. 42.
} 


\begin{tabular}{|c|c|c|c|c|c|c|c|}
\hline Letter & Value & Letter & Value & Letter & Value & Letter & Value \\
\hline 5 & 40 & $\tau$ & 8 & د & 4 & 5 & 40 \\
\hline د & 4 & J & 200 & هـ & 5 & س & 60 \\
\hline$\tau$ & 8 & م & 40 & $\dot{j}$ & 700 & ج & 3 \\
\hline هـ & 5 & ق & 100 & i & 1 & د & 4 \\
\hline ب ب & 2 & د & 4 & أ & 1 & \multirow{2}{*}{\begin{tabular}{|c|} 
Total \\
values
\end{tabular}} & \multirow{2}{*}{1302} \\
\hline م & 40 & ج & 3 & J & 30 & & \\
\hline
\end{tabular}

Tab.no.1: Shows the date of the renewal works of Jamill pasha 1302 AH according to His $\bar{a} b$ al-jumal in the last verse of the inscription.

The main iwan is composed of an irregular area, running $14.20 \mathrm{~m}$ along its southern wall is $14.20 \mathrm{~m}, 10.95 \mathrm{~m}$ along its northern wall, and $12.47 \mathrm{~m}$ along its longitudinal axis from the entrance to the mihrab. This area is divided by two arcades, each with two columns (Pl. 6); the arcades divide the iwan into three aisles. The first and the third aisle is divided into square areas roofed by cross vaults, while the middle aisle is roofed by semi-cross vaults (Fig. 2). The square area in front of the mihrab is roofed by a dome with pointed sector which rises over an octagonal drum. The drum composes of eight ribs, each of which includes a window surmounted by a pointed arch and based on transition zones from spherical triangle pendentives (Fig. 6; Pl. 7).

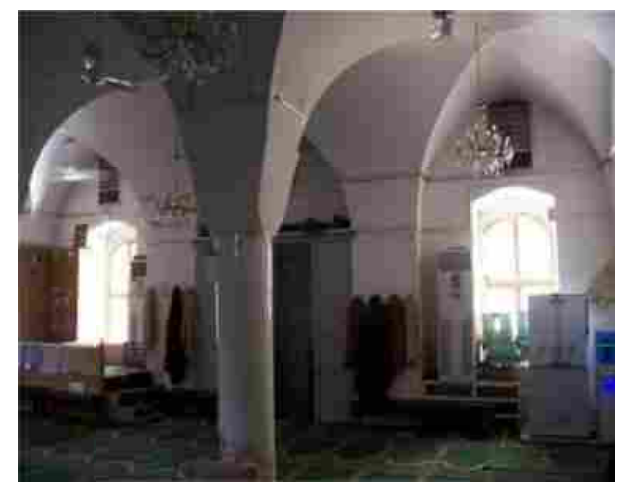
4P1.no.6:Insid e the main iwan al- Qiblīyah. By the author in July 2010. - Pl.no.7: The dome over the mihrab of the main iwan. By the author in July 2010..

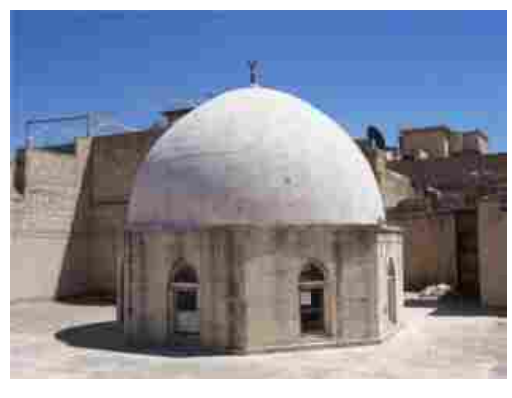

Regarding the mosque ceiling, it is founded on the cross vaults used to roof all areas inside the mosque except the square of the mihrab, which was roofed by a dome (Fig. 2). The cross vault is an architectural element that was used in widely since the preIslamic period, especially in Roman architecture. It was then used in Islamic architecture and appeared for the first time in the early Syrian architecture in Quseir 'Amrā in Jordon of 86-96 AH/ 705- $715 \mathrm{AD}^{69}$. It appeared for the first time in Egyptian architecture in the Fatimid period in the mosque of al-Juy $\bar{u} s h \bar{\imath}$ of $478 \mathrm{AH} /$ 1085 AD. The cross vault was an essential element for the ceiling in the city of Aleppo, being in widespread use since its first appearance early in the Islamic period. The most famous example of this element appears in the great Omayyad mosque, which has been completely roofed in this way.

${ }^{69}$ Shāfi 'ì, Al-'Imārah al- 'arabìyah, p. 198.

- 217 - Al-Karīmīyah Mosque in Aleppo, Syria: An Architectural \& Archaeological Study 
Beside the cross vaults, the architect used the dome over the square of the mihrab (Fig. 6; Pl. 7). The first example of this feature appeared in the great Omayyad mosque in Damascus founded in $97 \mathrm{AH} / 705 \mathrm{AD}^{70}$. It spread after that to be used in many buildings, such as: al-Aqsa mosque in Jerusalem after the construction of the Abbasid caliph al-Mahdi in $163 \mathrm{AH} / 780 \mathrm{AD}$; the dome of al-Kairouan mosque in Tunis which was added by Abū Ibrāhīm Ahmad Ibn al-Aghlab in 248 AH/ 862 AD; and the dome of the grand mosque in Cordoba which was added by al-Hakam II in $354 \mathrm{AH} / 965 \mathrm{AD}^{71}$. It also appeared in an early period in Egyptian architecture during the Fatimid dynasty in al-Azhar in 359-361 AH/ 790-792 AD and al-Häkim mosque of 380-403 AH/ 990-1013 $\mathrm{AD}^{72}$. It is a customary style for ceilings in Aleppo city. It appears in many buildings of various dates, such as: al-Asadīyah al-Jüwanīyah madrasa beside $B \bar{a} b$ Qinnasrin, which belong to the Zanki period ${ }^{73}$; alShädhbakhtīyah and al- 'Adīmīyah madrasa, of the Ayyubid period ${ }^{74}$; and Mihmindār mosque, which belongs to the Mamluk period ${ }^{75}$.

In the middle of the southern wall of the main iwan, there is the main mihrab. It measures $2.50 \mathrm{~m}$ in height, its width is $1.10 \mathrm{~m}$, and its depth is $88 \mathrm{~cm}$. It consists of a niche surmounted by a pointed arch decorated with prominent ribs emanating from the center to form a radiological shape (Pl. 8). The mentioned ribs are prominent and each ends with a stalactite tail ${ }^{76}$. Beside the mihrab to the right side is a wooden minbar ${ }^{77}$, devoid of decoration and inscriptions except simple geometrical frames around the orator's seat (Fig. 8). It also painted with new paint that distorts its archaeological features.

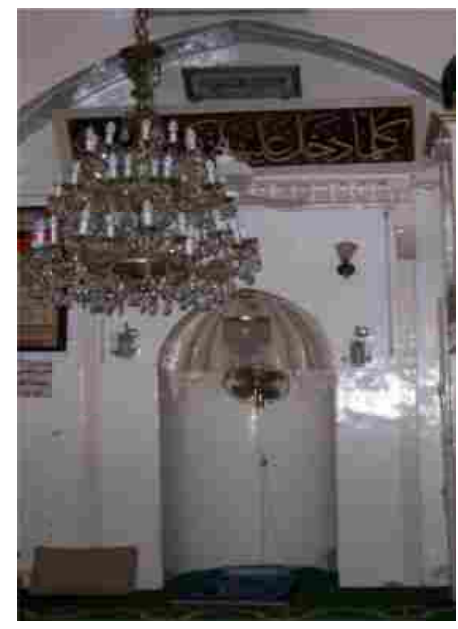

Pl.no.8: The mihrab of the main iwan. By the author in July 2010.

Fig.no.8: a side view and a plan of the minbar. Al-Jāsir, Dūr almutașawifah, p. 235.
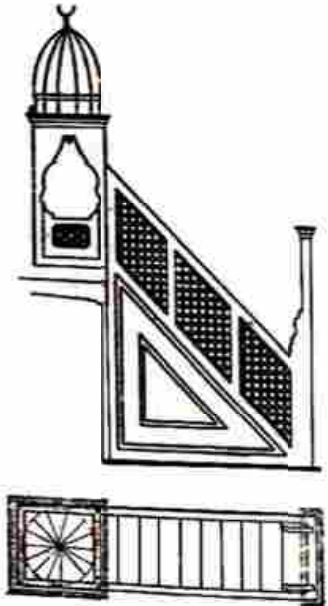

\footnotetext{
${ }^{70}$ Lam '̄i, Al-QiBāb fi al-'imarah al-islāmīyah, p. 19.

${ }_{71}$ Creswell, Early Muslim architecture, p. 121.

72 Sāmiḥ, "Tațwor al-qūbbah", p. 10.

${ }^{73}$ al-Jāsir, Madāris halab, p. 127.

${ }_{75}^{74}$ al-Jāsir, Madāris ḥalab, pp. 165, 224.

${ }^{75}$ Abd al-Rāzik, "Architectural archaeological study", p. 151.

${ }_{77}^{76}$ al-Jāsir, Dūr al-mutașawifah, p. 234.

77 The minbar consists of two parts; the first one is the orator's seat which is fixed in the wall and is surmounted by a small ribbed copula. The second part includes the ladder, the two sides, and the front door. This part is movable to be in its location only during the Friday sermon, then it is moved in a side corner inside the iwan. al-Jāsir, Dūr al-mutașawifah, p. 234.
} 
In the western side of the southern wall, there are two small doors measuring 1.60 high and $1 \mathrm{~m}$ wide, both of which are surmounted by curved arches (Fig. 2). The first door leads to a two-story room with an irregular area located behind the mihrab. It is used as a residence for the mosque's Imam. Its width along the western side is $3 \mathrm{~m}$ and from the eastern side is 3.50 , while its length is $6.40 \mathrm{~m}$. The second door leads to the second floor of this same room, via a stone staircase (Figs. 2, 9).

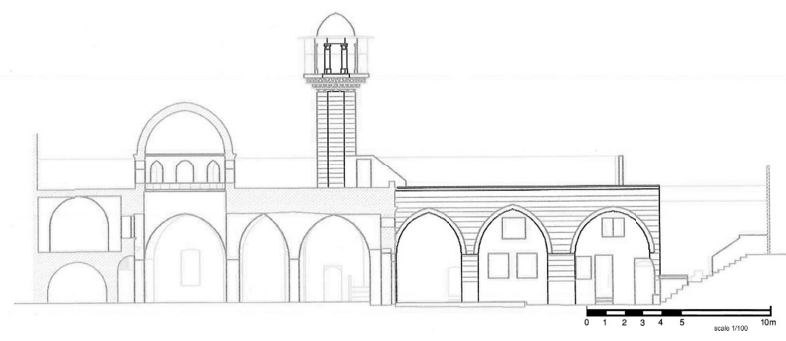

fig.no.9: Sector inside the main iwan, the imam's room, and the minaret. After, the center of planning and archaeological studies in Aleppo..

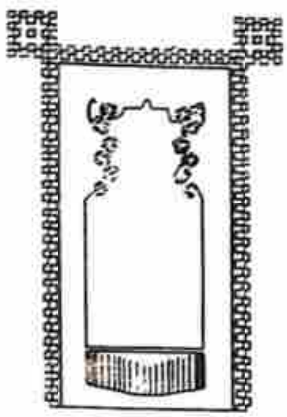

fig.no.10: The original decorations around the footprint. Al-Jāsir, Dūr al-mutașawifah, p. 235.

The southern wall of the main iwan includes also a footprint on a yellow marble slab, it was surrounded by a simple stone frame (Fig. 10) which is replaced now by marble decorations surmounted with an inscription includes al-Basmalah and verse 56 Surat $a l-a h z \bar{a} b^{78}$ (Pl. 9).

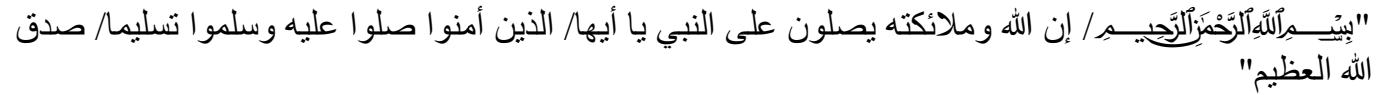

The footprint attributed to the prophet Muhammad. It is located on the eastern side of the southern wall, and is shown on this side of the mosque to allow people to ask blessings from it (P1. 9). It was associated with a story mentioned in historical sources which refer to the slab being brought to the mosque by al-Shaykh Abd al-Karim, who saw in his dream a man coming from Hijäz riding a camel and hiding a footprint attributed to the prophet Muhammad in his possessions. As the man passed in front of the mosque, al-Shaykh Abd al-Karim blocked his way, extracted the footprint and put it inside the mosque ${ }^{79}$.

Some historical sources mention the story of this footprint, such as al- Tabbākh (A 'läm, V, pp. 288, 289), who noted that it was illogical to attribute it to the prophet Muhammad for many reasons. Firstly, its yellow stone, known as al-Hirqalī, originates from quarries located near the city of Aleppo itself, not in al-Hijazz. He also pointed out that if it was really attributed to the prophet Muhammad, it would not have been ignored by previous historical authors such as Ibn al-Shuhnah and Ibn alHanbali, who presented biographies of al-Shaykh Abd al-Karīm and narrated complete chapters about the blessed places and monuments in Aleppo but make no mention of the slab. He assumed also that this stone was not a blessed prophetic monument because if it were, the Ottoman sultans would likely have transmitted it to Istanbul as they did with many other blessed monuments in Syria, such as the footprint founded inside the citadel of Bușrā.

${ }^{78}$ al-Jāsir, Dūr al-mutașawifah, p. 234.

79 al-Ṭabbākh, A 'lām al-nublā', vol. 5, p. 288.

- 219 - Al-Karīmīyah Mosque in Aleppo, Syria: An Architectural \& Archaeological Study 
In any case, we cannot be absolutely certain whether this footprint is attributed to the prophet Muhammad or not, as there are many examples around the Islamic world and most of them are similar with no distinguishing marks from each other ${ }^{80}$. The most important example is located inside the dome of the rock in Jerusalem, but others are preserved in al-Táa if in Saudi Arabia, on Mount Abu Zubaìydah. It is found also in Cairo in the mausoleum of Qāitbāy in al-Qaräfah ${ }^{81}$ and masjid athar al-nabi ${ }^{82}$. The city of Aleppo included other examples, such as the footprint of the mosque of Baqūsā.

\subsection{The eastern portico}

The eastern portico is located in the eastern side of the courtyard, which it overlooks through a triple arcade composed of three pointed arches based on two pillars. The arcade is now closed, however, with a new barrier. It was renewed in the Mamluk period during the works of al-Shaykh Abd al-Karim in $855 \mathrm{AH} / 1451 \mathrm{AD}^{83}$. The portico comprises a rectangular area of $12.05 \mathrm{~m}$ length and $9.23 \mathrm{~m}$ width. It was divided into two aisles through a middle arcade composed of three pointed arches, built on two pillars; the two aisles were divided into six square areas roofed by cross vaults (Fig. 2).

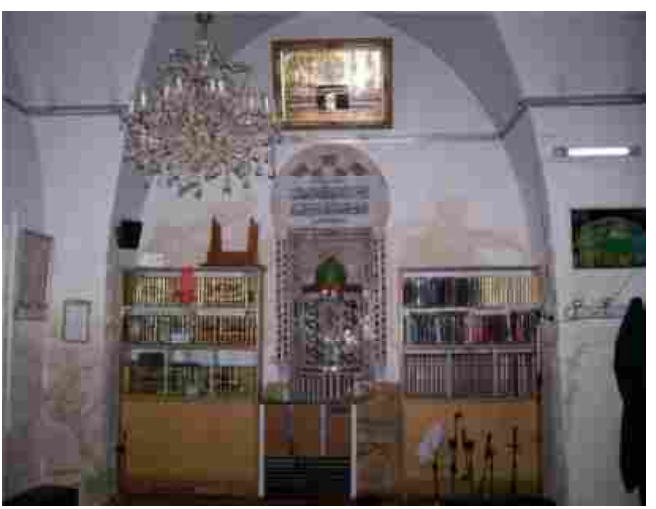

Pl.no.9: A footprint in a yellow stone slab inside the main iwan attributed to the prophet Muhammad. By the author in July 2010.

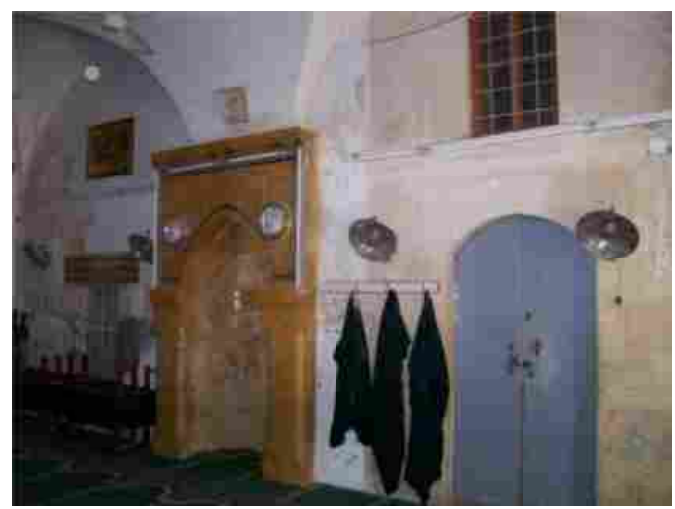

Pl.no.10: The southern wall of the eastern portico, the entrance of the mausoleum, and the inscription above the mausoleum's window. By the author in July 2010.

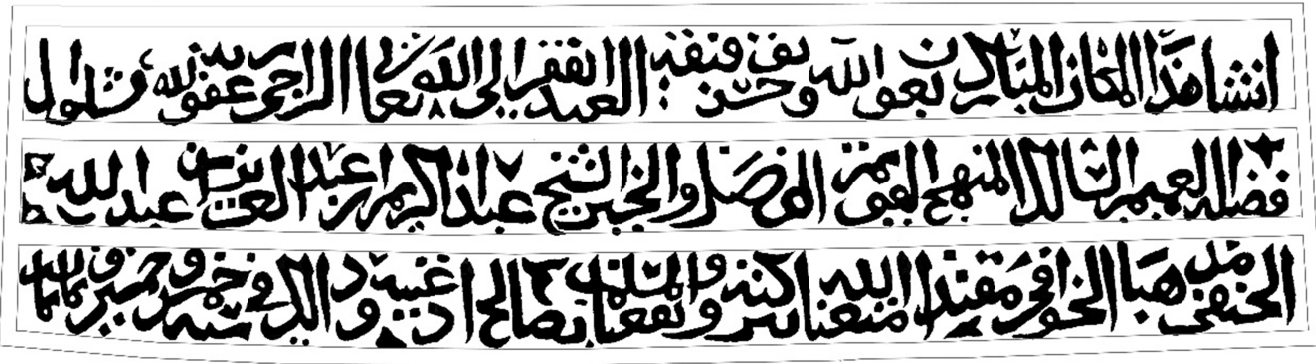

Fig.no. 11: The Mamluk inscription of al-Shaykh Abd al-Karim al-Khäfi above the mausoleum's window inside the eastern portico. Facsimiled by the author.

\footnotetext{
${ }^{80}$ For more information about this regard look: Tymūr, al-Athār al-nabawiyah, pp. 45-59.

${ }^{81}$ Coeli, Walker, Muhammad in History, p. 519.

${ }^{82}$ Tymūr, al-Athār al-nabawiyah, pp. 45-47.

${ }^{83}$ Ibn al-Ajamī, Kunūz al-dhahab, vol. 1, p. 256.
} 
In the middle of the southern wall, there is a mihrab composed of a rectangular frame. The niche inside is 2.30 high, $65 \mathrm{~cm}$ deep and $95 \mathrm{~cm}$ wide. It is very simple and devoid of decoration and inscriptions. In the right side of the mihrab, there is a door leading to the mausoleum, $2.15 \mathrm{~m}$ high and $1.10 \mathrm{~m}$ wide, surmounted by a curved arch. Above the door, there is a window $1.12 \mathrm{~m}$ height and $70 \mathrm{~cm}$ wide, which is surmounted by a curved arch and covered by an iron grille (Pl. 10). In the left side of the mihrab there is another window overlooking the mausoleum, measuring $95 \mathrm{~cm}$ high and $80 \mathrm{~cm}$ wide. Above the window is a monumental inscription ${ }^{84}$ that includes three Thuluth lines carved prominently in the stone (Fig. 11). The inscription commemorates the renewal works of al-Shaykh Abd al-Karīm in 855 AH/ 1451 AD.

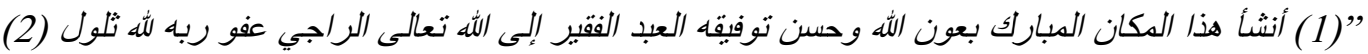

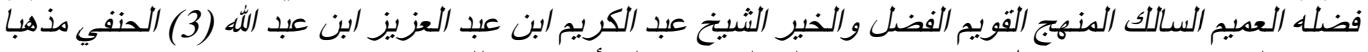

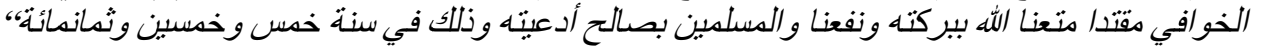

"(1)With the helping of Allāh, this blessed place was constructed by the poor slave to Allāh who wishes the pardon of his God (2) who follows the correct way al-Shaykh Abd al-Karīm Ibn Abd al-' Azīz Ibn Abdullāh (3) al- Hanafì al-Khawāfì Allāh enjoy us with his blessing and benefit us and the Muslims with his good prayers in 855",

The eastern side of the iwan includes three recesses roofed by pointed vaults which overlook the inside of the iwan via pointed arches, although these are closed now with new barriers, and connected with the iwan by doors and windows. The northern side of the iwan includes one recess roofed by pointed vaults which also overlooks the iwan through a pointed arch.

\subsection{The extensions of the mosque}

The mosque includes many extensions, some of which date back to the Mamluk period during the renewal works of al-Shaykh Abd al-Karim in $855 \mathrm{AH} / 1451 \mathrm{AD}$; others have been recently added. The mausoleum is considered the most important extension. It was added by al-Shaykh Abd al-Karim as his own tomb ${ }^{85}$ and he was actually buried here after his death in $884 \mathrm{AH} / 1479 \mathrm{AD}^{86}$.

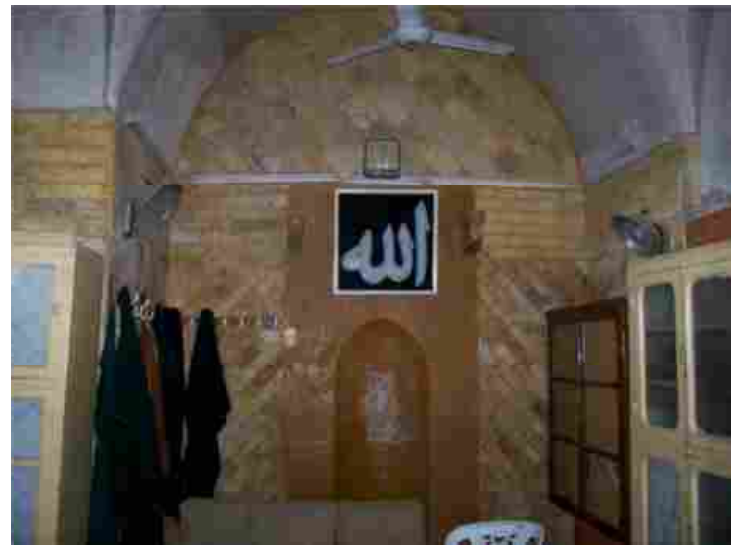

Pl. no.11: The mihrab of the mausoleum. By the author in July 2010.

\footnotetext{
${ }^{84}$ This inscription was previously published by Herzfeld (1955, p. 315).

${ }^{85}$ Miencke, Die Mamlukische architektur, p. 372.

${ }^{86}$ Ibn al-Hanbalī, Durr al- habab, vol. 1, p. 839.
} 
The mausoleum is located in the eastern side of the main iwan and is separated from it by a small room with an irregular area roofed by cross vaults, used for ablutions. The mausoleum comprises of a square area surmounted by four recesses, the square area measured $3.50 \mathrm{sq} \mathrm{m}$. It is roofed by a dome with a pointed sector rising on an octagonal drum and based on transition zones from spherical triangle pendentives (Fig. 6). Around the square area, there are four recesses with different areas roofed by pointed vaults. The southern recess includes the mihrab, composed of a small niche surmounted by a pointed arch (Pl. 11). This mihrab is the fourth one inside the mosque, the others previously mentioned in the south wall of the courtyard, and inside the main iwan and the eastern portico.

The multiplicity of the mihrabs is a phenomenon that appeared in religious building in many parts of the Islamic world from early on. It appeared in Egypt from the Fatimid period in Mashhad al-Saìydah Kolthom 516 AD/ 1122 AD and Mashhad al- Saīydah Ruqaiyah $527 \mathrm{AH} / 1133 \mathrm{AD}^{87}$. The repetition of mihrabs inside the same building was probably due to the multiplicity of religious doctrines or because the renewal works undertaken at each building used the mihrabs as a memorials of each renewal phase, such as the mihrabs of Ibn Tülūn mosque in Cairo ${ }^{88}$. The renewal works that added many extensions to the mosque of al-Karimiyah may be a suitable reason for the multiplicity of the mihrabs inside it. A multiplicity of mihrabs is common in Syria generally, appearing in the great Omayyad mosque in Damascus and then spreading to many buildings in the same city. In Aleppo, there are also many building that include more than one mihrab, such as: al-Hallawiyah madrasa of $543 \mathrm{AH} / 1148 \mathrm{AD}$, which includes three mihrabs ${ }^{89}$; Minkali Bugha mosque of 769 AH/ 1367 AD, which includes three mihrabs ${ }^{90}$; and Mihmindār mosque dating to $8^{\text {th }} \mathrm{AH} / 14^{\text {th }} \mathrm{AD}$, which includes five mihrabs ${ }^{91}$.

The northern recess includes a small door that connects the mausoleum and the eastern portico. The eastern recess includes an open arch that connects the mausoleum and another rectangular room, of $3.30 \mathrm{~m}$ length and $2.10 \mathrm{~m}$ width and roofed by cross vaults. The eastern side of the rectangular room includes a recess $2.95 \mathrm{~m}$ long and $1.35 \mathrm{~m}$ wide, roofed by a flat wooden roof, while its northern side includes a window overlooking the eastern portico, in which the inscription has been engraved. (Fig. 2).

The phenomenon of the attached mausoleum within religious buildings is a customary idea in Islamic architecture in general. The mausoleum of the prophet Mohammed is considered the first example of this phenomenon, becoming incorporated inside the borders of the mosque after the renewal works of al-Amir 'Umar Ibn Abd al-Azizz in 88-91 AH/ 707-710 AD during the reign of the Omayyad Caliph al-Walìd Ibn Abd al$\operatorname{Malik}^{92}$. The attached mausoleum appeared in Egypt for the first time during the

\footnotetext{
${ }^{87}$ Lam '̇̀, Al-Türāth al-mi`mārī, p. 44.

${ }^{88}$ Māhir, Masājid misr, p. 149.

89 al-Jāsir, Madāris halab, p. 108.

${ }^{90}$ Abd al-Rāzik, "Al-Rumi "Menkali Bogha" mosque”, p. 143.

${ }^{91}$ Abd al-Rāzik, "Architectural archaeological study", pp. 151-153.

92 al- Haddād, Al-Q̄̄bāb fì al- 'imārah al-misrīya, p. 31.
} 
Fatimid period in Mashhad al- Juyūshi $478 \mathrm{AH} / 1085 \mathrm{AD}^{93}$, the second example appeared during the Ayyubid period in al-Madāris al-Sālīhīyah 647-648 AH/ 1249$1250 \mathrm{AD}$, and then it became widespread in Mamluk architecture ${ }^{94}$.

The mausoleum was attached to religious buildings in Syrian architecture since an early period. The first example occurred when Nür al-Dìn Mahmūd constructed his school in Damascus in $567 \mathrm{AH} / 1172 \mathrm{AD}$ and attached a mausoleum for himself ${ }^{95}$. After this, it spread widely in the Syrian cities especially in Damascus and Aleppo. In Aleppo, it appeared in many examples, such as the mosque of al-Tunbughā $718 \mathrm{AH} /$ $1318 \mathrm{AD}$ and the mosque of al-Atrūsh $812 \mathrm{AH} / 1409 \mathrm{AD}^{96}$.

Among the extensions of the mosque are the toilets, which are located in the northeastern side of the courtyard. These were added during the renewal works of alShaykh Abd al-Karim ${ }^{97}$. They can be reached through one door in the northwestern side of the eastern portico and another in the northeastern side of the courtyard. Beside the toilets from the western side, there is a square hall recently added to the mosque, which can be reached through a staircase in the same side and it is currently used in memorizing the holy Quran and teaching jurisprudence sciences.

In the western side of the courtyard, there is an irregular room ${ }^{98}$ measuring $7.50 \mathrm{~m}$ long from north to south, $4.95 \mathrm{~m}$ wide along its southern side and $4.30 \mathrm{~m}$ along its northern side. It is isolated from the courtyard through a new barrier and can be reached now through one door in its southern side. It also includes two windows in its western side overlooking the façade of the mosque.

Regarding the general plan of al-Karimīyah mosque, including all architectural elements previously described, it is very similar to the Mamluk mosques in Aleppo city, as the principal renewal works at the mosque occurred during the Mamluk period. Therefore, the majority of the architectural units and the decorative details inside the mosque are homogenous with a style attributed to the same period.

The Mamluk mosques in the city of Aleppo are characterized by simplicity and a small size. The majority of them have the principal iwan in the south side of the courtyard called al-Qibliyah and another portico or iwan in the eastern side, in addition to the extensions that comprise a mausoleum, Qastal, toilets and service rooms ${ }^{99}$. In terms of the general plan of al-Karimiyah mosque, it has the same characteristics, that include an iwans in the southern side, a portico in the eastern side and extensions in the other sides, all of which share one courtyard in the center (Fig. 2 ). This plan is repeated in many other mosques in the same city, such as the mosque

${ }^{93}$ Shāfí 'ì, "The Mashhad al-Juyushi”, p. 237.

${ }^{94}$ Lam'ī, Al-QiBäb fi al-'imarah al-islāmìyah, p. 27.

${ }^{95}$ Kessler, "Funerary architecture", p. 259.

${ }^{96} \mathrm{Ibn}$ al-Shuhnah, Al-Durr al-muntakhab, pp.72, 73.

${ }^{97}$ Ibn al-AJamī, Kunūz al-dhahab, vol. 1, p. 256.

${ }^{98}$ The historical sources mentioned that this room was used as a kuttab to teach children. Al-Ghuzzi, nahr, p. 98; Some references referred that a part of its area was reduced from the northern side to be a kitchen. al-Jāsir, Dūr al-mutașawifah, p. 237.

99 'Uthmān, Al-Handasah al-'insh 'ìyah, p. 214. 
of al-Mihmindār in al-Bandarah district $8^{\text {th }} \mathrm{AH} / 14^{\text {th }} \mathrm{AD}$, although this has an external aisle in the northern side ${ }^{100}$. The same basic plan also appears in the mosque of Ughilbik in al-Bāb al-ahmar district dating to $885 \mathrm{AH} / 1485 \mathrm{AD}$, which has an iwan in both south and eastern sides in addition to the courtyard.

\section{THE ENDOWMENTS OF THE MOSQUE}

Many endowments were allocated to the al-Kariminah mosque inside and outside Aleppo. The waqf book was lost but it was mentioned by al-Ghuzzī (Nahr, II, pp.100101) who presented an abbreviated narration of the endowments allocated to the mosque. They included many endowments inside Aleppo city and other districts outside it (table 2). All these endowments have now disappeared and have been replaced by other buildings constructed during later periods. The waqf book is attributed to al-Shaykh Abd al-Karim and dates to 862 AH/ 1458 AD.

The abbreviated Arabic transcription of the waqf as mentioned by al- Ghuzzī (Nahr, vol. 2, pp.100-101):

$$
\begin{aligned}
& \text { ”خالصة وقف جامع الكريية الذي وقفه الثيخ عبد الكريم بن زين الدين بن عبد العزيز بن جمال الدين بن عبد }
\end{aligned}
$$

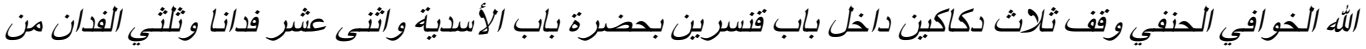

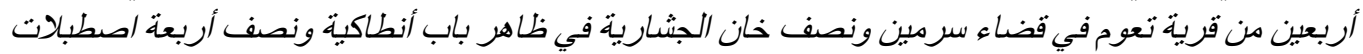

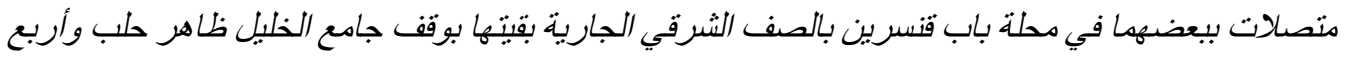

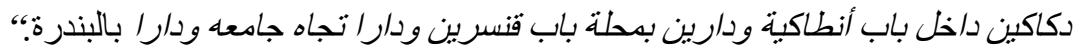

\begin{tabular}{|c|c|c|c|}
\hline No. & The endowments & Its location & Notes \\
\hline 1. & Three shops. & $\begin{array}{l}\text { inside } B \bar{a} b \text { Qinnasrin, beside } \\
\text { al-Asadìyah school, Aleppo. }\end{array}$ & - \\
\hline 2. & $\begin{array}{l}\text { Twelve acres and } \\
\text { one third. }\end{array}$ & $\begin{array}{l}\text { Ta wum village which follows } \\
\text { Sarmin }\end{array}$ & $\begin{array}{l}\text { Beside the city of Idlib in } \\
\text { current time. }\end{array}$ \\
\hline 3. & $\begin{array}{l}\text { Half of al- } \\
\text { Jishārinyah Khan. }\end{array}$ & Outside $B \bar{a} b$ Antakya, Aleppo. & - \\
\hline 4. & $\begin{array}{l}\text { Half of four adjacent } \\
\text { stables. }\end{array}$ & $\begin{array}{l}\text { Inside the district of } B \bar{a} b \\
\text { Qinnasrin, Aleppo. }\end{array}$ & $\begin{array}{l}\text { the other half of these four } \\
\text { stables was allocated to al- } \\
\text { Khalīl mosque outside } \\
\text { Aleppo. }\end{array}$ \\
\hline 5. & Four shops. & Inside $B \bar{a} b$ Antakya, Aleppo. & \\
\hline 6. & Two houses. & $\begin{array}{l}\text { Inside the district of } B \bar{a} b \\
\text { Qinnasrin, Aleppo. }\end{array}$ & - \\
\hline 7. & One house. & $\begin{array}{l}\text { Beside al-Kariminyah mosque, } \\
\text { Aleppo. }\end{array}$ & - \\
\hline 8. & One house. & $\begin{array}{l}\text { Inside the district of al- } \\
\text { Bandarah. }\end{array}$ & $\begin{array}{l}\text { Beside } a l-Q \bar{a} d \bar{\imath} \text { mosque } \\
\text { which still survived in its } \\
\text { location. }\end{array}$ \\
\hline
\end{tabular}

Table 2. Shows the endowments of al-Shaykh Abd al-Karim al-Khäfì on his mosque according to (al-Ghuzzī, Nahr vol. 2, pp. 100-101).

As usual, the waqf book includes the founder's stipulations for spending the yield of the waqf, that proceeds riy' should be spent first and foremost on the current upkeep of the waqf property, and on its development, construction, renovation and

${ }^{100}$ Abd al-Rāzik, “Architectural archaeological study”, p. 146. 
restoration ${ }^{101}$. Fortunately, the founder's stipulations were mentioned in al- Ghuzzī (Nahr, II, pp.100-101) (table 3).

The Arabic transcription of the founder's stipulations as mentioned by al- Ghuzzī (Nahr, 2: 100-101):

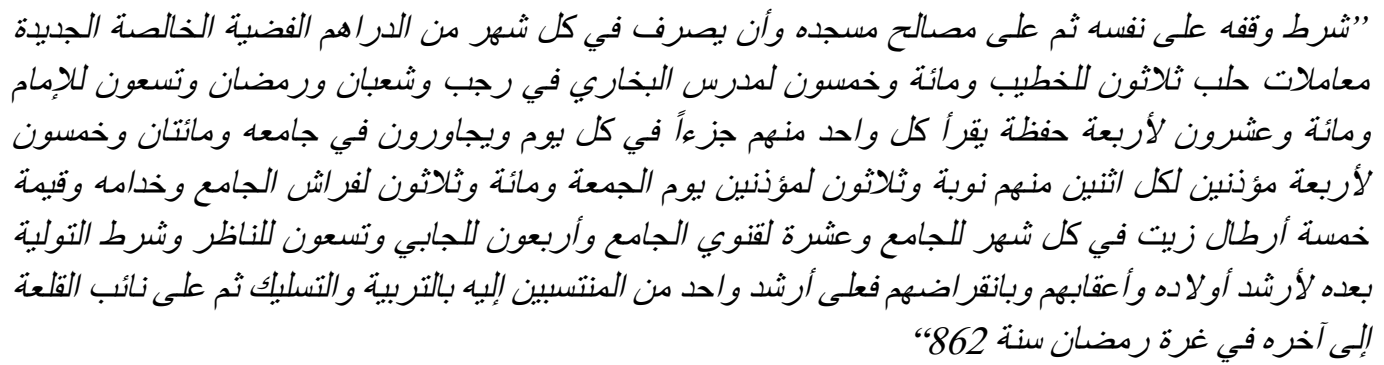

\begin{tabular}{|c|c|c|c|c|}
\hline No. & Value & Duration & Beneficiary & Notes \\
\hline 1. & \begin{tabular}{|l|}
30 silver pure \\
dirhams, traded \\
in Aleppo
\end{tabular} & Every month & The orator & $\begin{array}{l}\text { Who delivers the Friday } \\
\text { sermon }\end{array}$ \\
\hline 2. & 150 dirhams & $\begin{array}{l}\text { During the three } \\
\text { months Rajab, } \\
\text { Sha'bān, and Ramadān }\end{array}$ & $\begin{array}{l}\text { The teacher } \\
\text { of al- } \\
\text { Bükhāry }\end{array}$ & $\begin{array}{l}\text { Who teaches the Hadiths } \\
\text { of the prophet al- Hadī } \underline{t} \\
\text { al-Nabawi }\end{array}$ \\
\hline 3. & 90 dirhams & Every month & $\begin{array}{l}\text { The mosque's } \\
\text { imam }\end{array}$ & $\begin{array}{l}\text { Who leads people in } \\
\text { prayers }\end{array}$ \\
\hline 4. & 120 dirhams & Every month & $\begin{array}{l}\text { Four } \\
\text { memorizers } \\
\text { of Quran }\end{array}$ & $\begin{array}{l}\text { Each one of them read } \\
\text { every day inside the } \\
\text { mosque one part of the } \\
30^{\text {th }} \text { parts of the Quran }\end{array}$ \\
\hline 5. & 250 dirhams & Every month & ezzins & $\begin{array}{l}\text { o, responsible of } \\
\text { rk }\end{array}$ \\
\hline 6. & 30 dirhams & Every Friday & $\begin{array}{l}\text { Mue } \\
\text { of Fr }\end{array}$ & $\begin{array}{l}\text { Who call for prayer in } \\
\text { Friday }\end{array}$ \\
\hline 7. & 130 dirhams & Every month & vant & $\begin{array}{l}\text { Who guard and serve the } \\
\text { mosque }\end{array}$ \\
\hline 8. & \begin{tabular}{|l|} 
Value of 5 \\
pounds of oil \\
\end{tabular} & Every month & $\begin{array}{l}\text { The } \\
\text { mosque }\end{array}$ & Used in lighting the lamps \\
\hline 9. & 10 dirhams & Every month & Al-Qanawāt $\bar{\imath}$ & $\begin{array}{l}\text { Who cleans the source of } \\
\text { the water }\end{array}$ \\
\hline 10. & 40 dirhams & Every month & $A l-J a \bar{a} b \bar{\imath}$ & $\begin{array}{l}\text { Who collects the yield of } \\
\text { the waqf }\end{array}$ \\
\hline 11. & 90 dirhams & Every month & $A l-N \bar{a} z \bar{l} \bar{r} r$ & $\begin{array}{l}\text { Who supervises on the waqf, } \\
\text { the founder stipulated that } \\
\text { the supervision should pass } \\
\text { after this person to his older } \\
\text { son al-arshad fa-l-arshad }\end{array}$ \\
\hline$\frac{1}{0}$ & \multicolumn{4}{|c|}{$\begin{array}{l}790 \text { dirhams were the total proceeds spent in one month of the year plus } 150 \\
\text { dirhams spent during the three months Rajab, Sha bann, and Ramadān in } \\
\text { addition to the value of } 5 \text { pounds of oil every month. }\end{array}$} \\
\hline
\end{tabular}

Table 3. Shows the stipulation of the Waqf book of al-Karimiyah mosque.

${ }^{101}$ Raymond, "Les grand waqfs", p. 114; Raymond, La ville arabe, Alep, p. 170; Layish, "Waqfs of Awlad al-Nas", p. 318. 
It is apparent that the waqf of al-Karimiyah was extensive during the Mamluk period, for huge proceeds were spent on the mosque. These proceeds can be estimated each year at 9480 dirhams (790 every month $\times 12$ ) plus 450 dirhams spent in Rajab,

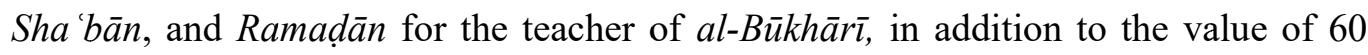
pounds of oil ( 5 pounds every month). The total proceeds spent each year were therefore estimated at 9930 dirhams plus the value of 60 pounds of oil.

In addition to the waqf of al-Shaykh Abd al-Karim, there were likely other endowments for the mosque by Jamil Pasha in the Ottoman period, although no record of these survives. The historical sources do not mention any notes about allocating new endowments to the mosque during the works of Jamil Pasha. The two inscriptions that commemorate his works are also limited to mentioning the renovations only, without any notes on endowments. Despite this, it can be assumed that the works of Jamil Pasha were not confined to renovating the mosque, but also included allocating endowments. This supposition is based on the inscription mentioned by Gaube (1978, p. 42) - previously mentioned in discussing the renewal works - which was located in a shop beside the mosque, and referred to the shop itself being endowed on the mosque in $1302 \mathrm{AH} / 1885 \mathrm{AD}$ (Fig. 12).
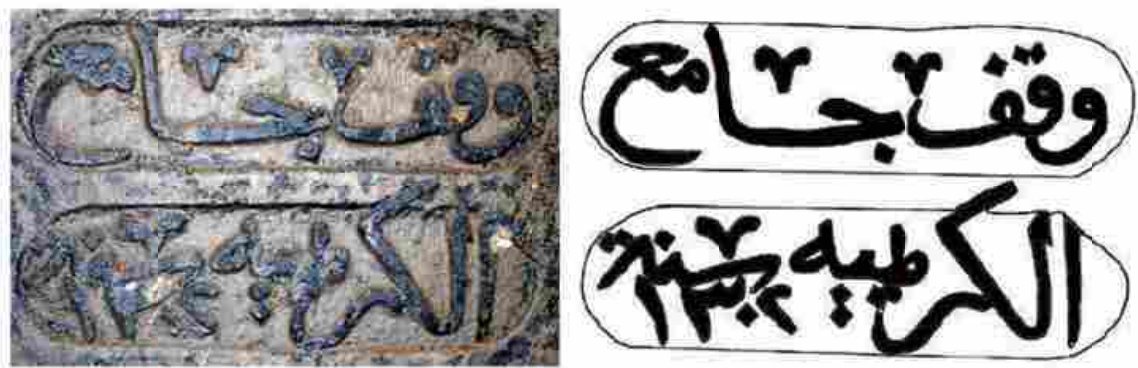

Fig .no.12. The inscription of the endowments of Jamīl pasha on al-Kariminyah mosque. After, 'Uthmān, Dirasat naq'ish, p. 149.

As noted, this date is the same as that of the renewal works of Jamil Pasha at the mosque itself and the historical sources do not refer to any works around this date except those attributed to him. Although Gaube (1978, p. 42) referred only to the shop that included the mentioned inscription, this does not mean that this waqf was confined to it. The waqf may have been large and included many endowments that had a great role in developing the mosque.

\section{CONCLUSION}

This case study concerns a significant archaeological building in its own right. The alKarimiyah mosque is considered one of the oldest mosques of the city of Aleppo. It is suggested that an approximate date for its first construction can be pinpointed during the $1^{\text {st }}$ century $\mathrm{AH}$ until the first year of the $2^{\text {nd }}$ century $\mathrm{AH}$. After this, various renewal works developed its architecture during the Ayyubid, Mamluk, and Ottoman periods. The study corrected what was assumed by some previous studies that the date $654 \mathrm{AH}$ is the date of construction and proved that this is the date of the first renewal works. The renewal works that occurred at the mosque in $1302 \mathrm{AH}$ in the Ottoman period by Jamīl pasha were not limited to renovation works but also included building 
construction as a waqf. The study determined the significant roles that the mosque played in the city during the various historical periods, as it performed a range of functions including that of Madrasa, Khanqāh, Zāwìyah, mausoleum, and shrine. The study proved that there is no relation between the current minaret and the minaret of Ibn Abi Sawāda, which was added to the mosque in $771 \mathrm{AH}$, and proposes that the current minaret was completely rebuilt during either the renewal works of al-Shaykh Abd al-Karìm in $855 \mathrm{AH}$ or in $866 \mathrm{AH}$ during the works of al-Amir Jānī Bik al-Tājī. Finally, the mosque had many endowments allocated to it by al-Shaykh Abd al-Karim in the Mamluk period, with proceeds spent on the mosque each year estimated at more than 9930 dirhams.

\section{ACKNOLEDGMENT:}

I would like to thank Dr. Anna Stevens - Senior Research Associate, McDonald Institute for Archaeological Research, University of Cambridge - for the linguistic review that greatly improved the manuscript. 


\section{REFERENCES}

1. Abd al-Rāzik (Mansour), Al-Hammamāt al- 'āmmah bi-madīnat halab mundh bidayat al'aṣr al-ayūbō wa-ḥatta nihāyat al- 'aṣr al- 'uthmāñ̄ (in Arabic= Public Baths in Aleppo since the beginning of Ayyubid period to the end of Ottoman state), al-Maktab al- 'arabī li1-m'ārif, Cairo, 2014.

2. Abd al-Rāzik (Mansour), Al-Ṭuruz al-mi 'mārīyah li-l-ma'adhin al-baqūyah bi-madīnat halab (in Arabic= architectural styles of surviving minarets in Aleppo), Waqay' ' ${ }^{\prime}$ Tārīkhīyah 20 (2014), Cairo, 299-382.

3. Abd al-Rāzik (Mansour), Architectural archaeological study to Mehmendar mosque in Aleppo, Egyptian Journal of Archaeological and Restoration Studies (EJARS), Sohag univ, Vol. (2), (2015).

4. Abd al-Rāzik (Mansour), Al-Rumi "Menkali Bogha" mosque in Aleppo - architectural archaeological study", Egyptian Journal of Archaeological and Restoration Studies (EJARS), Sohag univ, Vol. (2), (2016).

5. Abd al-Rāzik (Mansour), Mosque of Bahram Basha and its endowments in Aleppo (Syria)" Scientific Culture, Vol. (1), (2017).

6. Al-Asadī (Khayar al-din), Ahy ä halab wa aswäqiha (in Arabic= the districts and souks of Aleppo), Dār qutaybah, Syria, 1990.

7. Al-'asqalanī (shihab ad-din), Inba' al-ghumur bi abna' al-'umur fi al-tarikh(in Arabic=news of numerous about sons of the age in the history), Muhmed khan (ed.), Vol. (5), Dar alkutub al- 'ilmiyah, Lebanon, 1986.

8. Al-' asqalanī (shihab ad-din), al-Durar al-Kaminah fi a yan al-mi'ah al-thaminah(in Arabic= the hidden pearls about the nobles of the eighth hundred), Abd al-Warith Muhamed (ed.), Vol. (3), Dar al-kutub al-'ilmiyah, Lebanon, 1997.

9. Al- Dhahabī (Shams ad-din), Siyar a 'lā al-nubalā'(in Arabic= the biographies of the nobles), Hassan Abd al-Mannan (ed.), Vol. (3), Bayt al-afkār al-dawlyah, Jordon, 2004.

10. Al-Ghuzzī (Kamil), Nahr al-dhahab fì tärīkh halab(in Arabic= the gold river in the history of Aleppo), Shawqī Sha ath (ed.), Vol. (3), Dār al-qalam al- 'arabī, Syria, 1999.

11. Al-Ḥaddād (Mohamed), Al-Qībāb fì al- imārah al-misryah al-islāmyah, al-qubbah almadfan, nash'atiha wa-tațawuriha hatta nihayat al- 'așr al-mamlūkī ((in Arabic= the domes in Egyptian Islamic architecture), Maktabat al-thqāfah al-dīnyah Egypt, 1993.

12. Al- Ḥimșī (Faiyz), Halab al-qadìmah (in Arabic= Ancient Aleppo), Manshurāt al-muduryah al- 'āmmah li-1-athār wa-1- mtāḥif, Syria, 1983.

13. Al-Jabbūrī (Abd al-salām), Al-mushaiyadat al-waqfiyah wa al-khiriyah fi biläd al-shām ibān al-asr al-mamlüki (in Arabic= endowment and charity buildings in the Levant during the Mamluk period), Dār al-kitab al-thaqafi, Jordon, 2014.

14. Al-Jabbūrī (Yahyya), Al-khat wa-l-kitäbah fĩ al-bilād al- 'arabyah (in Arabic= script and inscription in Arabian countries), Dār al-gharb al-islamī, Lebanon, 1994.

15. Al-Jāsir (Lamya'), Madäris halab al-atharyah (in Arabic= archaeological schools of Aleppo), Dār al-raḍwān, Syria, 2000.

16. Al-Jāsir (Lamya'), Dūr al-mutașawifah fi Halab, al-khanqahat wa al-rubuț wa al-zawayah wa al-takayah (in Arabic $=$ The houses of Sufis in Aleppo), Jam 'iyat al-'adiyat bi halab, Aleppo, 2008.

17. Al-Jirmānī (Bishūf), Tuhaf al-anba' bi-tärīkh Halab al-shahbä' (in Arabic= the wonderful news about the history of white Aleppo), Shawqī Sha ath (ed., trans.), Dār al-wasīm, Syria, 1992.

18. Al-Qusir (Abd al-Razik), Al-madakhil al-baqiyah li al- 'amā'ir al-islamiyah al-diniyah fi madinat halab min al-asr al-zinkī hatta nihayat al-asr al-uthmani- dirasah athriyah mi mariyah faniyah muqaranah 522-1337 A.H/ 1128-1918 A.D (in Arabic= survived entrances in regional Islamic monuments in Aleppo from Zangi period to the end of the end of the Ottoman period), $\mathrm{PhD}$, Islamic archaeology dep., faculty of archaeology, Cairo University, Cairo, 2018. 
19. Al-Sakhāwī (Shams al-din), Al-Daw' allāmi' li-ahl al-qarn al-tāsi'(in Arabic= the brilliance light of the natives of the ninth century), Abd Allaṭif Hassan (ed.), 6 vols, Dār aljīl, Lebanon, 1992.

20. Al-Ṭabbākh (Raghib), A 'lām al-nublā' bi-tārīkh halab al-shahbā'(in Arabic= the nobles of the history of white Aleppo), Muhammad Kamāl (ed.), 7 vols, al-Maṭ 'ah al-amīryah, Syria, 1983.

21. Burns (Ross), Aleppo, A history, Routledge, Taylor \& Francis, London, 2017.

22. Chehade (Nachat), Aleppo: Its structure and problems, Ekistics 12, no. 70 (1961), Athens 102-106.

23. Coeli (Fitzpatrick) \& Walker (Adam), Muhammad in History, Thought, and Culture: An Encyclopedia of the Prophet of God, ABC-CLIO, Santa Barbara, 2014.

24. Creswell (Keppel), The Evolution of the minaret with special reference to Egypt, the Burlington Magazine 48, no. 278, (1926), London 134-140.

25. Creswell (Keppel), Early Muslim architecture, Umayyad, Early Abbasid and Tulunids, the Clarendon press, Oxford, 1932.

26. David (Jan Claud) \& Hiritani (Maḥmud), Halab madinat al- tārīkh (in Arabic= Aleppo, the city of history), Shu 'a' lil nashr wa al-'ulūm, Aleppo, 2011.

27. Fares (Mohamed), The Great Umayyad mosque of Aleppo, Dār al-qalam al- 'arabī, Syria, 1997.

28. Gaube (Heinz), Arabische inschriften aus Syrien, in commission bai Franz Steiner Verlag, Wiesbaden, Lebanon, 1978.

29. Gaube (Heinz)\& Wirth (Eugen), Aleppo : historische und geographische Beiträge zur baulichen Gestaltung, zur sozialen Organisation und zur wirtschaftlichen Dynamik einer vorderasiatischen Fernhandelsmetropole, Șakhr al-'ulaby (trans.), Manshūrāt wizārat althaqāfah al-sūrīyah, Damascus, 2007.

30. Herzfeld (Ernst), Inscriptions et monuments d'Alep, Impremerrie de l'Institute Français d'Archéologie Orientale, Le Caire, 1955.

31. Hivernel (Jacques), Bâb al-Nayrab, un Faubourg d'Alep, Hors la Ville et dans la Cite. Études Rurales no. 155, (2000), 215-237.

32. Ibn al-Ajamī, Kun̄̄z al-dhahab fì tārīkh halab(in Arabic= the treasures of gold in the history of Aleppo), shawqī sha 'ath (ed.), 2 vols, Dār al-qalam al- 'arab̄i, Syria, 1997.

33. Ibn al-Hanbalī, Durr al- habab fì tārīkh halab(in Arabic= the nice pearls in the history of Aleppo), Maḥmūd Fakhūrī (ed.), 2vols, Manshūrāt wizārat al-thaqāfah al-sūrīyah, Syria, 1972.

34. Ibn al-Shuhnah, Al-Durr al-muntakhab fì tārīkh halab(in Arabic= the selected pearls in the history of Aleppo), Abdullah Darwīsh (ed.), 1 vol., Dār al-kitāb al-arabī, Syria, 1984.

35. Ibn al-Wardī ('Umar), tārīkh ibn al-wardī(in Arabic= the history of Ibn al-wardi), Dar alKutub al-'ilmiyah, Lebanon, 1996.

36. Ibn Habib (al-Hasan), Tadhkarit al-nabih fi ayam al-Mansur wa banih(in Arabic= Reminding the intelligent about the reign of al-Mansour and his sons), Matba it Dar alkutub, Cairo, 1976.

37. Ibn Shaddād, Al-A 'lāq al-khațīah fì zikr 'umrā' al-shām wa-l-jaz̄irah(in Arabic= the serious issues in mentioning the emirs of the Levant and the island), Dūminik Sūrdīyl (ed.), 3 vols, French Institute for Arabic Studies, Syria, 1953.

38. Kessler (Christel), Funerary architecture within the city, Colloque International sur l'Histoire du Caire, Cairo, 1969.

39. Lam'̄̄ (Ṣaliḥ), Al-Türāth al-mi 'mārī al-islāmī (in Arabic= Islamic architectural heritage), Dār al-nahḍah al-arabīyah, Lebanon, 1984.

40. Lam' '̄ (Ṣaliḥ), Al-QiBāb fi al- 'imarah al-islāmīyah (in Arabic=Domes in Islamic architecture), Dār al-nahḍah al-'arabīyah, Lebanon, 1987.

41. Layish (Aharon), Waqfs of Awlad al-Nas in Aleppo in the late Mamluk period as reflected in a family archive, Journal of the Economic and social history of the Orient 51, no. 2, (2008), 287-326.

42. Māhir (Su'ad), Masājid miṣr wa awlīyā'uha al-Ṣālihūn (in Arabic= The mosques of Egypt and its righteous saints), al-Majles al-a 'lā li-l-shi' ūwn al-islāmiyah, Egypt, 1971.

229 - Al-Karīmīyah Mosque in Aleppo, Syria: An Architectural \& Archaeological Study 
43. Meincke (Michael), Die Mamlukische architektur in Ägypten und Syrien (648/1250 bis 923/1517), Abhandlungen des Deutschen Archäologischen Institutes, Ägypten, 1992.

44. Nuṭfajī (Husām), fan al- imarah al-arabiyah wa al-islamiyah wa athäriha fi halab (in Arabic $=$ The art of Islamic architecture in Aleppo), Dar al-Qalam, Aleppo, 2012.

45. 'Uthmān (Najwa), Al-Handasah al-'insh' 'yyah fì masājid halab (in Arabic=structural engineering in the mosques of Aleppo), Ma had al-turāth al- 'ilmī, Syria, 1992.

46. 'Uthmān (Najwa), Al-'Athār wa-l-awābīd al-tārīkhīyah fí halab wa-killis wa- ghāaz̄i- 'intāb (in Arabic= Historical archaeology in Aleppo, Killis and ghazi intab), University of Aleppo, Syria, 2009.

47. 'Uthmān (Najwa), Dirasat naq'ish al-'ahd al-uthmān̄̄ fi muhfazat halab, al-mabañ̄ wa shawahid al-qubür (in Arabic= study of the inscriptions of the Ottoman period in Aleppo, buildings and tombstones), al-makatabah al-waqfiyah, Aleppo, 2010.

48. Qal'ajī (Abd al-Fattah), Halab al-qadīmah wa-l-hadīthah, asmā' iha wa hukkāmiha wa aḥdāthiha, abwäbiha wa aswäqiha wa ah̆̄y'iha (in Arabic=Ancient and modern Aleppo, its names, rulers, events, gates, souks and districts), Mü'ssasit al-risālah, Lebanon, 1989.

49. Petersen (Andrew), Dictionary of Islamic architecture, Routledge, 11 New Fetter Lane, London, 1996.

50. Raby (Julian), "Nur Al-Din, the Qastal al-Shu'aybiyya, and the Classical Revival" Muqarnas 21 (2004), 289-310.

51. Raymond (André), Les grand waqfs et l'oranisation de l'espace urbain a Alep et au Caire a l'époque Ottomane (XVI-XVII Siécles), Bulletin d'études orientales, Vol. (31), (1979).

52. Raymond (André), La ville arabe, Alep, à l'époque ottomane: (XVIe-XVIIIe siècles), Malaka Abiyad (trans.), Manshūrāt wizārat al-thaqāfah al-sūrīyah, Damas, 2007.

53. Roded (Ruth), Great Mosques, Zāwiyas and Neighborhood Mosques: Popular Beneficiaries of Waqf Endowments in Eighteenth- and Nineteenth-Century Aleppo. Journal of the American Oriental Society, Vol. (1), 1990.

54. Said (Abeer), Khanqahat misr hatta nihayat asr al-mamlīk al-bahriyah 648-784 A.H/ 12501382 A.D (in Arabic= Khanqah of Egypt until the end of the Mamluk period)", al-Ustāz 203, (2012), 1455-1489.

55. Sauvaget (Jan), Alep, Essai sur le Développement d'une Grande Ville Syrienne, des Origines au Milieu du XIX Siècle, Lebrairie Orientalist Paul Geuthner, Paris, 1941.

56. Sauvaget (Jan) \& Tyrwhitt (Jacqueline), “Aleppo” Ekistics 11, no. 67 (1961), Athens 387412.

57. Sāmị̣ (Kamal al-din), "Tațwur al-qūbbah fĩ al- imārah al-islāmīyah" (in Arabic= Development of the dome in Islamic architecture), Bulletin of the Faculty of Arts, Vol. (1), 1950.

58. Saouaf (Șuhī) \& Miller (George), Aleppo: Visitor's Guid. $2^{\text {st }}$ ed. Aleppo, Syria, 1964.

59. Shadi (Watfa) \& Bashar (Mustafa), Syrian Archaeological Heritage, Past and Present. Scientific Culture, Vol. (3), (2015), 1-14.

60. Shāfi $\overline{1}$ (Farid), West Islamic Influence on Architecture in Egypt- before the Turkish Period Bulletin of the Faculty of Arts, Vol. (2), 1954.

61. Shāfi 'i (Farid), The Mashhad al-Juyushi, Archaeological notes and studies, Studies in Islamic Art and Architecture in Honor of Professor Creswell, Cairo, (1965), 237-252.

62. Shāfi'ī (Farid), Al-'imārah al-'arabīyah fì mișr al-islāmīyah (in Arabic= Arabian architecture in Islamic Egypt), Al-Haì ah al-mișrīyah al- 'āmmah li-l-kitāb, Egypt, 1970.

63. Tabbaa (Yaser) "Circle of power: Palace, Citadel, and city in Ayyubid Aleppo, Ars Orientalis 23, (1993), 181-200.

64. Țalas (Mohamed), Al-'athār al-islāmīyah wa-l-tăà rīkhīyah fī halab (in Arabic= Historical and Islamic archaeology in Aleppo), Maț ' it al-taraqqī, Syria, 1956.

65. Tymūr (Ahmed), Al-'athär al-nabawiyah (in Arabic= Prophetic antiquities), Mu'sasit hidawī, Cairo, 2012.

66. Warren (John), Key monuments of Islamic architecture: Syria, Jordan, Israel, Lebanon Architecture of the Islamic world, Michell G. (ed.), (Thames \& Hudson Ltd, London, 1978.

67. Watentpaugh (Heghnar), The image of an Ottoman city, imperial architecture and urban experience in Aleppo in the $16^{\text {th }}$ and $17^{\text {th }}$ Centuries, Brill, Boston, 2004. 